\title{
Pre-Launch Exploration of Consumer Willingness to Purchase Selenium- and Iodine-Biofortified Apples-A Discrete Choice Analysis of Possible Market Settings
}

\author{
Ruth Kleine-Kalmer ${ }^{1, *}$, Adriano Profeta ${ }^{2} \mathbb{D}$, Diemo Daum ${ }^{1} \mathbb{D}$ and Ulrich Enneking ${ }^{1}$ \\ 1 Faculty of Agricultural Sciences and Landscape Architecture, Osnabrück University of Applied Sciences, \\ Am Krümpel 31, 49090 Osnabrück, Germany; d.daum@hs-osnabrueck.de (D.D.); \\ u.enneking@hs-osnabrueck.de (U.E.) \\ 2 DIL German Institute of Food Technology, Prof. von Klitzing Str. 7, 49610 Quakenbrück, Germany; \\ a.profeta@dil-ev.de \\ * Correspondence: r.kleine-kalmer@hs-osnabrueck.de; Tel.: +49-541-969-5092
}

check for updates

Citation: Kleine-Kalmer, R.; Profeta, A.; Daum, D.; Enneking, U. Pre-Launch Exploration of Consumer Willingness to Purchase Seleniumand Iodine-Biofortified Apples-A Discrete Choice Analysis of Possible Market Settings. Nutrients 2021, 13 1625. https://doi.org/10.3390/ nu13051625

Academic Editors: Alie de Boer and Lutz Schomburg

Received: 12 March 2021

Accepted: 6 May 2021

Published: 12 May 2021

Publisher's Note: MDPI stays neutral with regard to jurisdictional claims in published maps and institutional affiliations.

Copyright: (c) 2021 by the authors. Licensee MDPI, Basel, Switzerland. This article is an open access article distributed under the terms and conditions of the Creative Commons Attribution (CC BY) license (https:// creativecommons.org/licenses/by/ $4.0 /)$

\begin{abstract}
Selenium and iodine are essential micronutrients for humans. They are often deficient in food supply due to low phytoavailable concentrations in soil. Agronomic biofortification of food crops is one approach to overcome micronutrient malnutrition. This study focused on a pre-launch exploration of German consumers' willingness to purchase selenium- and/or iodine-biofortified apples. For this purpose, an online survey was carried out. In this context, consumers were asked to choose their most preferred apple product from a set card of product alternatives in a discrete choice experiment (DCE). The multinomial logit model results demonstrated that German consumers' have a particular preference for iodine-biofortified apples. Furthermore, apple choice was mainly influenced by price, health claims, and plastic-free packaging material. Viewed individually, selenium did not exert an effect on product choice whereas positive interactions between both micronutrients exist.
\end{abstract}

Keywords: biofortification; discrete choice; fruits; health claims; micronutrients

\section{Introduction}

Selenium and iodine are essential micronutrients for human health. They are responsible for the proper functioning of the thyroid and the immune system as well as for the prevention of cancer [1-3]. In large parts of Europe and other regions of the world, the selenium and iodine content in soils of agricultural land is relatively low [4-7]. As a consequence, the population exhibits deficiencies of the micronutrient due to the likewise low selenium content in agricultural products [2]. Iodine deficiency is a serious problem in Germany. Approximately one third of adults and children do not take in sufficient iodine [8,9]. Different measures have been taken in order to prevent the population from the resulting diseases. For example, table salt is often enriched with iodine and made available in supermarkets [10]. In contrast, a similar product containing selenium is not available thus far. However, the reference values for the daily intake of selenium are $60 \mu \mathrm{g}$ /day for women and $70 \mu \mathrm{g} /$ day for men in the DACH region (Germany, Austria, and Switzerland) [11]. Different agricultural practices have been applied that increased the supply of micronutrients in food. Examples include the supplementation of feed for livestock with the micronutrients selenium and iodine, resulting in increased levels of these micronutrients in meat and milk, respectively [12].

Another approach is the agronomic biofortification of crops where micronutrients are enriched in plants via fertilization. This technique proved to be effective in increasing the selenium and iodine content in plant-based food $[13,14]$. Recently, field experiments have been successfully carried out for apples and other fruits [15-18]. D'Amato et al. compiled numerous attempts of biofortification of food crops with selenium. The authors highlighted that biofortified selenium is well bioavailable for the human body due to its incorporation 
into organic compounds such as amino acids [19]. In addition, the biofortification of food crops may provide other benefits. For example, in experiments with pears and peaches, foliar selenium sprays resulted in increased soluble solids content and firmness of the fruits, respectively [20]. Furthermore, both selenium and iodine fertilization can promote the formation of valuable plant substances such as vitamin $C$ and phenolic compounds [21,22].

Biofortified crops serve as an example for natural functional food products. Here, the micronutrients were introduced during cultivation instead of processing [21]. Generally, functional foods include ingredients that provide specific health benefits in addition to their natural energy contribution [23]. Apart from serving as meals, their specific features can function as a source of micronutrients that is beneficial for human health $[23,24]$. Particularly in central and northern European countries, there is an increasing acceptance of functional foods that is mainly due to a change in health consciousness [25]. While a number of trials have been conducted on biofortification with selenium and iodine, only a few food products are currently available in Europe's food retail market for consumers. One exception is Finland, where the use of mineral fertilizers containing selenium became mandatory in the mid-1980s. This measure has improved the selenium supply of the Finnish population from a very poor status to a sustainably optimal level [14].

In a German consumer survey, Wortmann et al. examined whether fruits like apples were preferred over food supplements as a source of selenium by consumers. They found a higher acceptance for apples that were rich in selenium than for the corresponding food supplements [26]. Apples are among the most popular fruits for Germans [27]. They are also the most often cultivated crops within the fruit category in agriculture [28]. In addition, due to various food scandals in recent years, consumers have a higher trust in fruits that have been grown locally [29]. For this reason, selenium-rich apples were seen as a suitable food alternative to reach large parts of the German population by Wortmann et al. [26].

To embed this new research area in the existing literature, we found studies with analogies to the consumer acceptance of biofortified products. Wortmann et al. provided the first ideas of the general consumer's acceptance of biofortified apples, but they did not analyze the impact of product attributes in the framework of a purchase decision [26]. Another research project focused on consumers' willingness to pay for biofortified iodine vegetables in Africa [30]. Furthermore, consumer motivation to consume selenium-rich foods have been examined in Australia [31]. However, none of the two studies focused on apples or on German consumers. In contrast, the intake of the micronutrients selenium and iodine in the form of food supplements, but not biofortified apples, has been analyzed for German consumers [32].

Focusing on ordinary apples not regarding micronutrient content or biofortification, the existing literature of consumer behavior has focused on the influence of apple varieties and the related attributes like taste, sweetness, firmness, or crispiness [33-35]. In other studies, consumer preferences were measured by analyzing the impact of quality, price, reduced pesticide input, and packaging as well as organic or local origin [29,36]. In recent years, increasing attention has also been given to ecological packaging in Germany [37], in particular, plastic-free wrapping material for fresh food has become more important [38]. In order to inform consumers about the benefits of foods, producers often use authorized health claims [39]. These support the consumer's choices by suggesting appropriate products with respect to personal needs. Moreover, health claims often serve as marketing instruments because their beneficial contents add value to the original carrier products [40].

The literature indicated that the consumers' purchase decision on apples depended on a number of product attributes. Prior to the market launch of the new developed biofortified selenium and iodine apples, the impact of these attributes had not been explored and therefore constituted the main focus in this research. However, biofortified apples are not common products on the food market and German consumers were not familiar with them. The biofortification technique was too complex to explain in the supermarkets. Therefore, a consumer-friendly and market realistic presentation of the benefits of biofortified apples had to be developed. The central approach was communicating the health-related advan- 
tages. The two micronutrients and their impact on the body were declared in the form of health-claims and health-related slogans. In order to find out what influence traditional factors plus the new health-related benefits had on the purchase decision of consumers, a DCE designed as a realistic apple purchase situation was performed. Here, different product attributes were experimentally varied and statistically estimated. To sum up, we discuss a new horticultural approach to develop healthy apples that contribute essential and yet incomplete micronutrients to the German population. In addition, this research included an analysis of the consumer acceptance of newly developed biofortified selenium and iodine apples that have never before been tested in a choice experiment designed as a realistic market setting.

To our knowledge, the German consumers' willingness to purchase selenium- and iodine-biofortified apples has not been examined thus far. Individual product attributes that influence the purchase decisions of consumers in the supermarkets have not been analyzed for German consumers in the context of a shopping situation. These products have not been produced on a larger scale for retail yet. For this reason, the objective of this study was to close the gap between innovative aspects of the new biofortified apples that were ready for market entry on the one hand, and consumer preferences on the other. In the existing literature, no comparable research approaches could be found. This study opens a new, interdisciplinary field of research within the context of biofortification experiments with apples and consumer's willingness to purchase new biofortified apple products.

\section{Methods and Material}

\subsection{Data Collection and Survey Design}

Data were collected via online interviews in August and September 2019. A fully structured questionnaire was developed. The questionnaire included screening questions regarding the weekly purchase of fresh food, frequency of apple consumption, age, gender, and region. Only participants eighteen years and above who consumed apples at least once a month were allowed to participate, so only people doing the grocery shopping were included. In addition, participants were asked about their most often purchased apple varieties, their present consumption of food supplements, and their knowledge of micronutrients. Furthermore, the questionnaire included a concept description of biofortified selenium and iodine apples. The new biofortified apples with high contents of micronutrients were described and a picture of apple trees was shown for the first time. After the concept description, the DCE followed. More detailed information regarding the experimental design of the DCE is provided in Section 2.3. After respondents were asked to choose their preferred selenium and iodine apple product, a question including statements of further purchase motives of apples was attached. More detailed information regarding purchase motives is provided in Section 2.4 and in question 22 (see Appendix A). The reason for asking this question was to examine whether further product characteristics would affect the purchase decision of biofortified apples. The respondents were recruited and pre-screened for the main responsibility of household shopping by the respondi AG, who provided an online household panel for consumer research. The questionnaire was scripted using LimeSurvey software version 2.00. The collected data were prepared using the statistical software SPSS version 26 and Stata 15.1. $\chi^{2}$-tests were applied to analyze the differences between male and female response behavior. Factor analysis and multinomial logistic regression were carried out for more detailed statistical analysis. Data quality checks were implemented regarding the exclusion of incomplete interviews and interviews with a very short interview length. Interviews that failed the question for the level of attention were also excluded from the sample. Overall, $n=1042$ complete interviews with German consumers accepted for the analysis.

\subsection{Theoretical Background}

DCE is a standard method in consumer research to measure the preferences for new food products [41]. With regard to the research objective, the consumer's tradeoff between 
individual levels of attributes of the new selenium and iodine apple products in the purchase decision was analyzed. Consumers were asked to choose one apple product out of three from a set of offered alternatives. The estimated values from all choices are called utility values [42]. The framework for the analysis is called random utility theory and is based on McFadden's approach with an individual utility function for each consumer depicted in Equation (1) [43-45].

$$
U_{i n}=V_{i n}+\varepsilon_{i n}
$$

According to the random utility framework, each individual $n$ has an unobservable utility $U_{i n}$, which consists of an explainable share $V_{i n}$ and a random component $\varepsilon_{i n}$ of utility that is associated with choice alternative $i$. Assuming that $A$ is the set of all choice alternatives with $J$ elements, then the individual $n$ will choose option $i$ over another option $j$ if the following term applies:

$$
U_{i}>U_{j} \text { where } i \neq j \in A
$$

That is to say, the utility of option $i$ is larger than the utility of option $j$. Equation (3) shows the probability that individual $\mathrm{n}$ will choose option $i$ :

$$
P_{i n}=P\left[\left\{\varepsilon_{j n}-\varepsilon_{i n}\right\}<\left\{V_{\text {in }}-V_{j n}\right\}\right] \text { for } i \neq j \in A
$$

For the calculation of the choice probabilities, the distribution of the random component $\varepsilon_{i n}$ needs further specification based on McFadden's basic approach. Equation (4) shows the multinomial conditional logit model that is often applied in DCE:

$$
P_{i n}=\frac{e^{V_{i n}}}{\sum_{j=1}^{J} e^{V_{j n}}}, j=1, \ldots, J \text { and } j \neq i
$$

In order to calculate the multinomial conditional logit model in this research, attributes and levels of the biofortified apples had to be determined.

\subsection{Design of the Discrete Choice Experiment}

From the outside, biofortified apples do not differ from other apples and consumers are not able to distinguish between ordinary and biofortified apples. For the illustration in the online questionnaire, realistic apple products were needed. Several informal interviews were first conducted with producers of apples and scientific experts in the field of plant research. Based on their expertise and the above-mentioned criteria, the attributes in this DCE were developed. In order to demonstrate the specifics of the new biofortified apples to consumers, packaged apples were chosen over loose ones. The advantage of this form was that product information could be placed directly on the apples. For the DCE, choice sets were created as choice cards including varying product attribute combinations. They represented ordinary apple products that were available in German supermarkets in June 2019 based on market observations before the survey was conducted. Thereby, the focus of the respondents was not directly pointed at the novelty (the micronutrients selenium and iodine), but on the apple product as a whole. In order to find out which variables offered the highest utility in the choice of biofortified apples, the following questions were examined:

Q1: Which micronutrient combination is most preferable?

Q2: Which is the most preferable health-related slogan?

Q3: Which is the most preferable variety?

Q4: Which is the most preferable packaging material and format?

Q5: Will consumers of selenium and iodine food supplements have a higher acceptance of biofortified apples than non-consumers of food supplements?

Q1 focused on the two micronutrients selenium and iodine. They have not been offered to potential German consumers in form of biofortified apples yet. It was crucial 
to examine whether consumers preferred selenium or iodine or both micronutrients in combination. Additionally, one option without micronutrients was tested. This was the most realistic option for German consumers at that time because they had neither heard about biofortified apples nor seen them in retail yet.

Q2 focused on the information regarding the benefits of the new biofortified apples. Respondents were provided with basic background knowledge of the benefits of biofortified apples by testing the health claims "Contributes to the normal function of the immune system" and "Contributes to the normal production of thyroid hormones and normal thyroid function" [46]. In addition, one slogan describing the content of micronutrients and one slogan about the enjoyment of eating healthy and delicious apples were tested. It was crucial to find out which of the offered health-related slogans offered the highest utility to consumers.

In Q3, the most preferred varieties of the consumers were examined because previous research regarding the choice of apples has shown that varieties played an important role for consumers in the purchase decision. Varieties were associated with the preferred taste and had a positive effect on the choice of apples. In particular, club apples like Pink Lady ${ }^{\circledR}$ became more important [47]. The most preferred varieties by German consumers Elstar, Braeburn, and Pink Lady ${ }^{\circledR}$ were included in the DCE as well as a new developed brand named Selstar ${ }^{\circledR}[48]$.

Due to increasing awareness of sustainable purchasing behavior, consumers are paying more and more attention to the consequences of their shopping behavior. By choosing plastic-free packaging material, an increasing consumer segment contributes to the reduction of microplastics [37]. Additionally, the general reduction of waste and efforts that are required for recycling packaging material are coming to the fore [38]. Q4 consequently investigated the packaging material to find out if it affected the consumers' decision in the context of biofortified apples.

With regard to target groups for the new biofortified apples, the segment of buyers of food supplements was identified. The group revealed a higher acceptance for biofortified apples in previous research, mainly because they were familiar with food supplements to obtain particular micronutrients [26]. For this reason, the fifth question addressed potential groups of buyers to find out if the consumption of selenium and iodine food supplements affected the willingness to purchase biofortified apples positively.

To sum up, the attributes' packaging, health-related slogan, variety, "rich in" (micronutrients), and price were selected for the DCE (Table 1). The price levels were based on market observations in supermarkets. Overall, the DCE consisted of five attributes with four levels, except for packaging, which only had three levels.

Regarding the different formats of packaging, pictures were shown to the respondents in the choice sets. This supported the visual imagination of the new apple products in the online questionnaire. Since the packaging constituted the outer appearance of the new biofortified apples, it also had an impact on the initial impression of the potential consumers. For that reason, three types of packaging were used as labels (fixed label design) in the DCE and therefore did not vary on the set cards. The fixed label design was also taken into consideration later in the regression analysis. Packaging A comprised plain cardboard without imprints, which partly covered the apples. Packaging B was a plastic bowl with transparent plastic foil where the apples were completely covered but visible through the foil. Packaging $C$ comprised of color printed cardboard that covered most of the fruits. Below the pictures of the packaging was a banner including the healthrelated slogans. The prices were declared in Euros and referred to the entire product unit. Overall, the different apple products were always shown as version $\mathrm{A}, \mathrm{B}$, and C in one choice set with fixed ordering of packaging and varying health-related slogans, varieties/brands, micronutrients, and prices (Figure 1). Before the respondents were asked to make a choice from the displayed choice sets, the concept of the new biofortified apples was introduced at the beginning. The description was developed according to merchantable commercial material that briefly described the presence of both micronutrients and their 
benefits. The following text was shown to the respondents (compare section concept test and Q21 in Appendix A):

"In the next section, we would like to introduce to you a new kind of apple which is especially rich in selenium and iodine. Selenium and iodine are essential micronutrients which contribute significantly to the improvement of human health.

The first companies are currently launching the new biofortified apples in retail. Please imagine you are in a supermarket and would like to purchase a package of 6 apples. Which of the following apples would you choose?"

Overall, twenty choice sets were developed and randomly distributed among the sample (Appendix A Table A1). Figure 1 shows one example of a choice set.

In order to minimize the number of decisions in the online interview, the number of choice sets was reduced with the software Ngene version 1.2 [49]. Consequently, each respondent was shown one choice set and only had to pick one out of three offered alternatives for apple products. Herewith, an overload of choices, which often caused fatigue in the response behavior was avoided.

Table 1. Attributes and levels of the DCE.

\begin{tabular}{cc}
\hline Attributes & Levels \\
\hline Packaging ${ }^{1}$ & Cardboard foodtainer, banderoles, no print \\
Plastic bowl, plastic foil & \\
& Foodtainer, hardcover slipcase, color print \\
Tasty and healthy enjoyment & Naturally with micronutrients \\
Health-related slogan & Contributes to a normal functioning of the immune \\
& system \\
Contributes to a normal thyroid functioning \\
Elstar \\
Briety/brand \\
Praeburn \\
Pink Lady ${ }^{\circledR}$ \\
Selstar \\
Selenium \\
Iodine \\
Micronutrients (rich-in) \\
\end{tabular}

${ }^{1}$ The packaging was not rotated (i.e., remained in the same order).

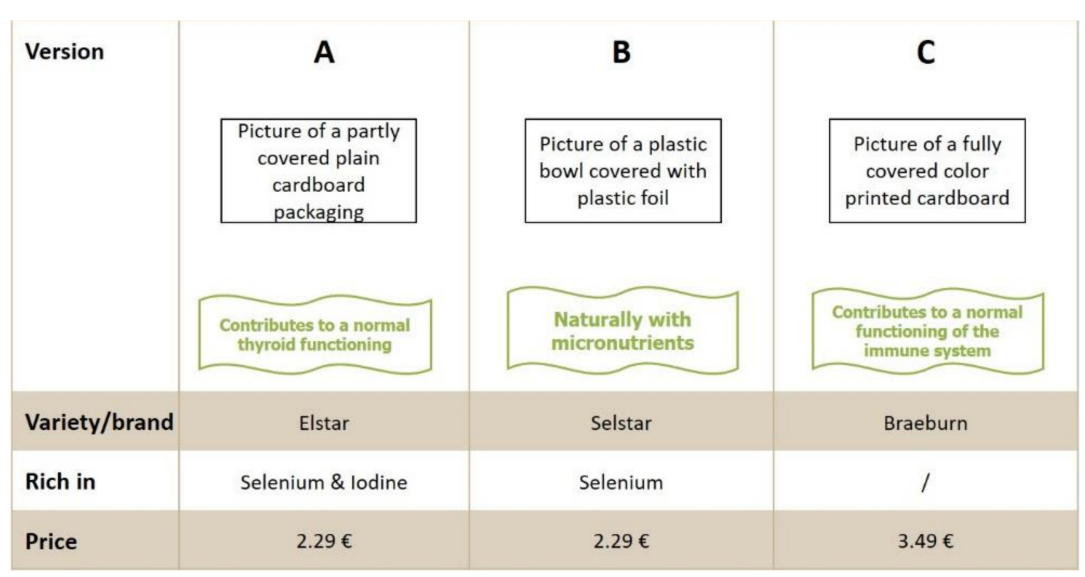

Figure 1. Example of one choice set card with three choices $(\mathbf{A}-\mathbf{C})$ out of a total of twenty set cards with different choice alternatives. 
Equation (5) describes the final estimated multinomial logit model of the statistical analysis. All experimental variables were included as well as the interaction terms of the micronutrients and the packaging, the interaction of selenium and iodine with food supplements and packaging, and the interaction of selenium and iodine with further motivations for purchasing the new biofortified apples and packaging. The interaction terms with packaging were considered because of the fixed label design of the DCE. The motivations to buy biofortified apples were condensed by means of factor analysis (Section 2.4) beforehand and refer to the additional benefits of the new apples that the respondents had to rate in Q22 of the questionnaire.

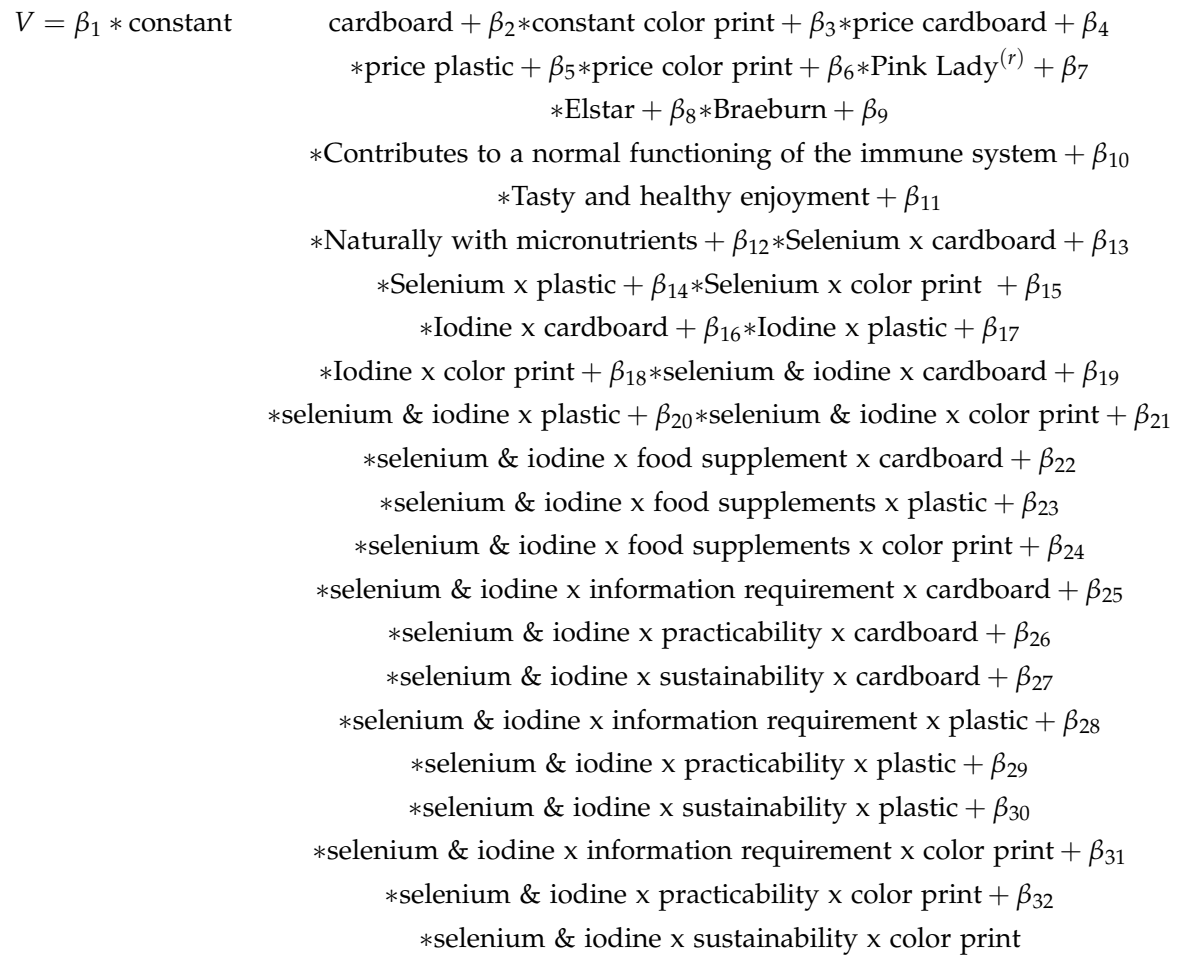

In this discrete choice study, the estimated $\beta$ coefficients indicate how the respective variable influences the choice of one of the three offered alternatives. The alternatives correspond to the three packaging formats. The corresponding $p$ values show whether the observed variable influences the probability of choosing the respective alternative significantly (three significance levels: ${ }^{* *} p \leq 0.001 ;{ }^{* *} p \leq 0.01,{ }^{*} p \leq 0.05$ ).

\subsection{Factor Analysis}

Factor analysis was applied in order to further examine the purchase motivations of apple products, which were integrated into the multinomial conditional logit model (Equation (5)). It is a common method applied in marketing research for the purpose of discovering invisible components that affect consumers' decisions. Steptoe et al. extracted nine factors as basic motives for selecting food. Among them were convenience, sensoryappeal, natural content, familiarity, or similar motivations [50]. A question regarding motives for purchasing biofortified apples was also developed for this research. Preformulated items and interval-scaled responses were included in the questionnaire. The respondents were asked to rate statements on a 5-point Likert-scale that ranged from "Is very appealing to me" to "Is not appealing to me at all". The terms were formulated as additional benefits of the new biofortified apples and reasons for purchasing them. Included were descriptions regarding the origin of the apples, sensory-appeal of the fruits, packaging specifics, and information regarding the production. Interviews including 
missing values were excluded from the factor analysis. The extracted factors were included in the discrete choice model.

\section{Results}

\subsection{Sample Description and Socio-Demographic Criteria}

After data preparation and quality checks, the final sample included a balanced distribution of gender with $51.4 \%$ female and $48.6 \%$ male respondents, as displayed in Table 2. About one third of the respondents were older than 54 years $(32.0 \%)$ and most of them lived in the densely populated western part of Germany (35.4\%), followed by the south with $27.6 \%$. Regarding the respondents' occupation, more than half were employed full-time (56.5\%), followed by $13.4 \%$ part-time, and $12.1 \%$ were retired. Generally, the level of employment was rather high. Regarding the educational level, $35.7 \%$ held a university degree. Considering household size, most interviewees lived in a household with two people $(38.2 \%)$ and $27.8 \%$ lived in a single household. Only very few respondents lived in households with five or more people. A total of $19.0 \%$ of all respondents had children under twelve years.

Table 2. Characteristics of survey participants and social-demographic criteria.

\begin{tabular}{|c|c|c|c|}
\hline \multirow{2}{*}{ Characteristic } & \multirow{2}{*}{ Unit } & \multicolumn{2}{|c|}{ Respondents } \\
\hline & & $\mathbf{n}$ & $\%$ \\
\hline Total & & 1042 & 100 \\
\hline \multirow{4}{*}{ Gender } & Female & 536 & 51.4 \\
\hline & Male & 506 & 48.6 \\
\hline & 18-24 years & 97 & 9.3 \\
\hline & 25-34 years & 195 & 18.7 \\
\hline \multirow{4}{*}{ Age } & $35-44$ years & 173 & 16.6 \\
\hline & $45-54$ years & 244 & 23.4 \\
\hline & $>54$ years & 333 & 32.0 \\
\hline & West & 369 & 35.4 \\
\hline \multirow{6}{*}{ Region } & South & 288 & 27.6 \\
\hline & North & 193 & 18.5 \\
\hline & East & 192 & 18.4 \\
\hline & Full-time employed & 589 & 56.5 \\
\hline & Part-time employed & 140 & 13.4 \\
\hline & Retired & 126 & 12.1 \\
\hline \multirow{7}{*}{ Occupation } & Student & 74 & 7.1 \\
\hline & Homemaker & 44 & 4.2 \\
\hline & Unemployed & 38 & 3.7 \\
\hline & Practical education & 14 & 1.3 \\
\hline & School & 7 & 0.7 \\
\hline & University degree & 372 & 35.7 \\
\hline & Secondary school & 277 & 26.6 \\
\hline \multirow{6}{*}{ Education } & High school diploma & 206 & 19.8 \\
\hline & Elementary school (Hauptschule) & 104 & 10.0 \\
\hline & Specialist/Master craftsman & 76 & 7.3 \\
\hline & Still attending school & 4 & 0.4 \\
\hline & 1 Person & 290 & 27.8 \\
\hline & 2 Persons & 398 & 38.2 \\
\hline \multirow{4}{*}{ Size of the household } & 3 Persons & 174 & 16.7 \\
\hline & 4 Persons & 127 & 12.2 \\
\hline & 5 Persons & 37 & 3.6 \\
\hline & More than 5 Persons & 16 & 1.5 \\
\hline \multirow{2}{*}{ Parenthood } & No children & 548 & 52.6 \\
\hline & Children under twelve years & 198 & 19.0 \\
\hline
\end{tabular}




\subsection{Consumption Habits of Apples and Food Supplements}

About a quarter of the respondents (24.1\%) ate apples on a daily basis and another $34.5 \%$ consumed apples several times a week. Overall, apples were part of the regular diet of most respondents and only a minor segment $(8.0 \%)$ of the respondents indicated eating apples only rarely. However, it must be noted that apple consumption was a mandatory screening criterion so that only people who ate apples at least once per month were considered for the survey. In the older age groups, there was a larger share of respondents who ate apples on a daily basis. A total $32.4 \%$ of consumers who were older than 54 years ate apples daily compared to $14.4 \%$ of consumers aged $18-24$ years. For the varieties, the results showed that Pink Lady ${ }^{\circledR}$ was mentioned as the most often purchased variety with a share of $23.8 \%$ (Table 3 ). It was also the most often purchased variety by women with $25.9 \%$ and men with $21.5 \%$. Braeburn ranked second with $12.6 \%$ of all mentions. However, looking at the differences between men and women, it can be noted that whereas women ranked Braeburn second with 14.4\%, Golden Delicious was the second most often purchased variety by men with $14.7 \%$. Only $10.7 \%$ of men chose Braeburn as their most often purchased variety. Therefore, in the case of Braeburn, a difference in the purchasing behavior between men and women was recorded. The third most often purchased variety was Elstar, with $12.0 \%$ of all mentions and $11.0 \%$ of men and $13.1 \%$ of women. As depicted in Table 3, Pink Lady ${ }^{\circledR}$, Braeburn, and Elstar were the most often purchased varieties for $48.4 \%$ of German consumers.

Table 3. Most often purchased apple varieties of German consumers by gender.

\begin{tabular}{|c|c|c|c|c|c|c|}
\hline \multirow{2}{*}{ Varieties } & \multicolumn{2}{|c|}{ Total $^{1}$} & \multicolumn{2}{|c|}{ Male } & \multicolumn{2}{|c|}{ Female } \\
\hline & $\mathbf{n}$ & $\%$ & n & $\%$ & n & $\%$ \\
\hline Pink Lady ${ }^{\circledR}$ & 239 & 23.8 & 104 & 21.5 & 135 & 25.9 \\
\hline Braeburn & 127 & 12.6 & 52 & 10.7 & 75 & 14.4 \\
\hline Elstar & 121 & 12.0 & 53 & 11.0 & 68 & 13.1 \\
\hline Golden Delicious & 103 & 10.3 & 71 & 14.7 & 32 & 6.1 \\
\hline Jonagold & 94 & 9.4 & 47 & 9.7 & 47 & 9.0 \\
\hline Granny Smith & 68 & 6.8 & 32 & 6.6 & 36 & 6.9 \\
\hline Boskoop & 61 & 6.8 & 29 & 6.0 & 32 & 6.1 \\
\hline Gala & 40 & 4.0 & 20 & 4.1 & 20 & 3.8 \\
\hline Red Delicious & 37 & 3.7 & 21 & 4.3 & 16 & 3.1 \\
\hline
\end{tabular}

Comparison male and female respondents: $x^{2}: p=0.002 ; 1 \mathrm{n}=1005$; only varieties with more than $3.0 \%$ of mentions are displayed.

Regarding the knowledge about the two micronutrients iodine and selenium, consumers were asked to choose only those micronutrients from a list that they had heard of before. Generally, the overall awareness of iodine $(71.3 \%)$ was much higher than the awareness of selenium (46.9\%) (see Table 4). Furthermore, there was a difference in the awareness of the two micronutrients between men and women. A total of $76.3 \%$ of all women were aware of iodine and in contrast, $66.0 \%$ of all male respondents had ever heard about iodine $\left(\chi^{2}: p \leq 0.001\right)$. In the case of selenium, the female share was $51.9 \%$ and the share of men was only $41.7 \%\left(\chi^{2}: p=0.001\right)$. In addition, the respondents were asked to choose those micronutrients from a list that they had previously consumed in the form of food supplements. A difference in the consumption between selenium and iodine was found. A total of $19.3 \%$ of all respondents had consumed iodine in the form of food supplements and $12.5 \%$ had consumed selenium in the form of food supplements. 
Table 4. Knowledge of selenium and iodine as well as consumption as a food supplement by gender.

\begin{tabular}{|c|c|c|c|c|c|c|c|}
\hline \multirow{2}{*}{ Micronutrients } & \multirow{2}{*}{ Status } & \multicolumn{2}{|c|}{ Total } & \multicolumn{2}{|c|}{ Male } & \multicolumn{2}{|c|}{ Female } \\
\hline & & $\mathrm{n}$ & $\%$ & $\mathbf{n}$ & $\%$ & $\mathrm{n}$ & $\%$ \\
\hline \multirow{2}{*}{ Iodine $* * *$} & Stated awareness & 743 & 71.3 & 334 & 66.0 & 409 & 76.3 \\
\hline & Unaware & 299 & 28.7 & 172 & 34.0 & 127 & 23.7 \\
\hline \multirow{2}{*}{ Selenium $* * *$} & Stated awareness & 489 & 46.9 & 211 & 41.7 & 278 & 51.9 \\
\hline & Unaware & 553 & 53.1 & 295 & 58.3 & 258 & 48.1 \\
\hline \multirow{4}{*}{$\begin{array}{l}\text { Iodine as food } \\
\text { supplement (n.s.) } \\
\text { Selenium as food } \\
\text { supplement } * * *\end{array}$} & Consumers & 201 & 19.3 & 86 & 17.0 & 115 & 21.5 \\
\hline & Non-consumers & 841 & 80.7 & 420 & 83.0 & 421 & 78.5 \\
\hline & Consumers & 130 & 12.5 & 42 & 8.3 & 88 & 16.4 \\
\hline & Non-consumers & 912 & 87.5 & 464 & 91.7 & 448 & 83.6 \\
\hline
\end{tabular}

Comparison male and female respondents: $\chi^{2}$ : ${ }^{* * *} p \leq 0.001$, n.s. $p \geq 0.05$.

In the consumption patterns, a difference between men and women could be observed. A total of $21.5 \%$ of the women declared that they had consumed iodine as a food supplement compared to $17.0 \%$ of men. However, the difference was not significant $\left(\chi^{2}: p=0.068\right)$. In the case of selenium, the difference was significant and higher with $16.4 \%$ of women who had consumed selenium as a food supplement and $8.3 \%$ of men $\left(\chi^{2}: p=0.000\right)$. Hence, iodine was the more common micronutrient and was also more often consumed as a food supplement than selenium. Additionally, women were more often aware of both micronutrients and consumed both of them more often in the form of food supplements.

\subsection{Results of the Factor Analysis}

Only items with factor loadings with values larger than 0.5 were displayed (Table 5). The extracted factors explained $59.1 \%$ of the variation and were allocated to three different factors. Therefore, it was assumed that the extracted components contributed well to explaining the measured variance of the purchase motives of the new biofortified apples.

Table 5. Rotated component matrix of principal component analysis and allocation to factors.

\begin{tabular}{ccc}
\hline Factors & Statements & Factor Loadings \\
\hline & Produced in Germany & 0.84 \\
Produced locally/nearby & 0.82 \\
Sustainability & Organically grown & 0.72 \\
& Freshly picked and crispy & 0.69 \\
& Plastic-free packaging & 0.66 \\
& Intense fruity taste & 0.65 \\
& Integrated production & 0.52 \\
\hline Practicability & Warranty of long shelf life fruits & 0.72 \\
& Intense red fruit peel & 0.70 \\
& Aesthetically appealing packaging & 0.69 \\
Information requirements & Easy to open & 0.65 \\
& Handy, medium fruit size & 0.57 \\
& Popular apple variety 'Elstar' & 0.52 \\
\hline & Imprint: Certified by University Medical Center Charité Berlin & 0.78 \\
& Further information available on the Internet (e.g., via QR code) & 0.71 \\
& Especially suitable for low allergy nutrition & 0.70
\end{tabular}

KMO-criterion: 0.914.

The three extracted factors can be described as follows:

Factor 1: This was called sustainability because it encompassed regional, seasonal, and freshness aspects of the apples. It consisted of statements with high factor loadings addressing the country of origin (Germany) and the region of production of the apples, which was close to the respondents' homes. Additionally, it included a statement regarding organic cultivation. Moreover, the time of harvest loads highly on this factor as well as the statement regarding the plastic-free packaging material. Intense fruity taste and integrated production are the last two terms that loaded on the first component.

Factor 2: This was called practicability and included ideas regarding a long shelf life, intense red fruit husk, and an aesthetically appealing packaging. In addition, the statement 
regarding the easy opening of the packaging loaded highly on this factor. Finally, the statement regarding the well-known and third most often purchased variety 'Elstar' loaded highly on this factor. This is called practicability because mainly items regarding reduced efforts in the handling of apples and simplifying choice loaded on this factor.

Factor 3: This was called information requirement and comprised additional information regarding suitability for vegan and vegetarian nutrition. Additionally, the certification of the University Medical Center Charité Berlin loaded highly on this factor. One term regarding the availability of further information on the Internet and the information regarding the suitability for low allergies nutrition were also included in this factor. Generally, the factor comprised ideas regarding specific information and safety and spent details on the product.

\subsection{Results of the Discrete Choice Analysis}

In the DCE-model, most of the analyzed parameters revealed positive effects on the apple choice except for the price, which exerted a negative effect. However, the intensity of the effects differed considerably (Table 6). For the micronutrients, the findings showed that selenium did not have a significant effect on the willingness to purchase apples. None of the coefficients of the interaction terms of selenium and the packaging were significant. In contrast, the interaction coefficient of iodine and the cardboard packaging $\left(0.64^{*}\right)$ as well as iodine and the plastic container $\left(0.68^{*}\right)$ were significant, whereas only the coefficient of the color print packaging was not significant. However, the interaction of both micronutrients and the color print packaging had a significant positive effect. Remarkably, the coefficient was 0.73 * and had a higher effect than in the case of the interaction of iodine and the other two packaging variants. With the color print packaging, the combination of both micronutrients had a stronger effect than each micronutrient individually.

The results also showed that the health claim regarding the normal functioning of the immune system had the strongest impact $\left(0.80^{* * *}\right)$ on the willingness to purchase the new biofortified apples. The slogans "Tasty and healthy enjoyment" $\left(0.51^{* * *}\right)$ and "Naturally with micronutrients" $\left(0.54^{* *}\right)$ were also significant and positive. Concerning the varieties, Pink $\operatorname{Lady}^{\circledR}\left(0.60^{* * *}\right)$ and Elstar $\left(0.40^{* *}\right)$ both had a significant and positive effect whereas neither Braeburn nor Selstar ${ }^{\circledR}$ showed such effect. The interaction term of both micronutrients, cardboard container, and information requirement was $0.45^{* *}$ and had a significant positive effect. However, the effect of the interaction of both micronutrients, cardboard container, and sustainability was stronger with a positive and significant coefficient of $0.64^{* * *}$. In the interaction of both micronutrients, plastic packaging, and purchase motives, there was only one statistically significant negative coefficient of $-0.38^{* *}$ in the case of sustainability. Color print packaging, both micronutrients and purchase motives did not show significant coefficients. The interaction terms of both micronutrients, the consumption of selenium and iodine as food supplements, and the packaging did not have any effects either. In contrast to all the other variables, the price consistently had a statistically negative effect on the willingness to purchase for all packaging formats. The strongest negative effect of the price was measured for the cardboard packaging with a coefficient of $-1.16^{* * *}$, followed by $-0.68^{* *}$ in the case of plastic, and $-0.65^{* *}$ in the case of the color print.

Table 6. Results of the multinomial conditional logit model.

\begin{tabular}{ccc}
\hline & $\beta$ Coefficients & Standard Error \\
\hline Constants & & \\
\hline Constant cardboard & $2.0 *^{*}$ & 0.96 \\
\hline Constant color print & 0.22 & \\
\hline Interaction terms micronutrients (rich in) and packaging & & \\
\hline Selenium x cardboard & 0.05 & \\
\hline Selenium x plastic & 0.13 & 0.37 \\
\hline
\end{tabular}


Table 6. Cont.

\begin{tabular}{|c|c|c|}
\hline & $\beta$ Coefficients & Standard Error \\
\hline Selenium $\mathrm{x}$ color print & 0.23 & 0.24 \\
\hline Iodine $\mathrm{x}$ cardboard & $0.64 *$ & 0.25 \\
\hline Iodine $\mathrm{x}$ plastic & $0.68 *$ & 0.29 \\
\hline Iodine $\mathrm{x}$ color print & 0.21 & 0.29 \\
\hline Selenium \& iodine $x$ cardboard & 0.48 & 0.29 \\
\hline Selenium \& iodine x plastic & 0.48 & 0.28 \\
\hline Selenium \& iodine $x$ color print & $0.73 *$ & 0.32 \\
\hline \multicolumn{3}{|l|}{ Nutrition and health claims } \\
\hline Contributes to a normal functioning of the immune system & $0.80^{* * *}$ & 0.17 \\
\hline Tasty and healthy enjoyment & $0.51 * * *$ & 0.14 \\
\hline Naturally with micronutrients & $0.54^{* *}$ & 0.16 \\
\hline \multicolumn{3}{|l|}{ Varieties } \\
\hline Pink Lady ${ }^{\circledR}$ & $0.60 * * *$ & 0.14 \\
\hline Elstar & $0.40^{* *}$ & 0.14 \\
\hline Braeburn & 0.21 & 0.14 \\
\hline \multicolumn{3}{|c|}{ Interaction terms micronutrients (rich in), purchase motives, and cardboard packaging } \\
\hline Selenium \& iodine $\mathrm{x}$ information requirement $\mathrm{x}$ cardboard & $0.45^{* *}$ & 0.16 \\
\hline Selenium \& iodine $x$ practicability x cardboard & 0.13 & 0.14 \\
\hline Selenium \& iodine $\mathrm{x}$ sustainability $\mathrm{x}$ cardboard & $0.64 * * *$ & 0.16 \\
\hline \multicolumn{3}{|c|}{ Interaction terms micronutrients (rich in), purchase motives, and plastic packaging } \\
\hline Selenium \& iodine $\mathrm{x}$ information requirement $\mathrm{x}$ plastic & 0.25 & 0.14 \\
\hline Selenium \& iodine x practicability x plastic & 0.16 & 0.15 \\
\hline Selenium \& iodine $x$ sustainability x plastic & $-0.38^{* *}$ & 0.14 \\
\hline \multicolumn{3}{|c|}{ Interaction terms micronutrients (rich-in), purchase motives, and color print } \\
\hline Selenium \& iodine $\mathrm{x}$ information requirement $\mathrm{x}$ color print & -0.10 & 0.15 \\
\hline Selenium \& iodine x practicability $x$ color print & 0.09 & 0.15 \\
\hline Selenium \& iodine $x$ sustainability $x$ color print & 0.13 & 0.15 \\
\hline \multicolumn{3}{|l|}{ Interaction terms micronutrients, food supplements, and packaging } \\
\hline Selenium \& iodine $x$ food supplement $x$ cardboard & -0.12 & 0.31 \\
\hline Selenium \& iodine $x$ food supplements $x$ plastic & -0.06 & 0.33 \\
\hline Selenium \& iodine $x$ food supplements $x$ color print & 0.50 & 0.35 \\
\hline \multicolumn{3}{|l|}{ Price } \\
\hline Price cardboard & $-1.16^{* * *}$ & 0.24 \\
\hline Price plastic & $-0.68 * *$ & 0.21 \\
\hline Price color print & $-0.65 * *$ & 0.21 \\
\hline
\end{tabular}

Pseudo $R^{2}$ : 0.11; Significance level ${ }^{* * *} p \leq 0.001 ;{ }^{* *} p \leq 0.01,{ }^{*} p \leq 0.05$.

\section{Discussion}

\subsection{Influence of Presence of Selenium and Iodine}

In the DCE, the micronutrient selenium alone did not have a significant effect on the willingness to purchase biofortified apples. One explanation for this could be the limited knowledge about selenium. Only $46.9 \%$ of the respondents had ever heard of selenium (Table 4). Considering the effect of iodine alone, the results of the discrete choice model turned out to be significant and positive. The consumers were more familiar with this micronutrient (71.3\%). Additionally, due to established functional foods like iodized salt, the insufficient supply of iodine as well as the presence of iodized food products in Germany was more commonly known [51]. This means that the majority of the respondents 
were also aware of the relevance of iodine for human health. The combination of both micronutrients affected the willingness to purchase the color print positively. Likewise, the effect here had the highest coefficient. On the one hand, this effect could be caused by the positive effects of iodine. On the other hand, this effect could also be carried by the assumption that the positive effect of iodine for health is reinforced by the presence of selenium. Possibly, the lack of knowledge about selenium and its positive effects on human health were counterproductive in the decision making process. With reference to Q1, it can be noted that iodine and both micronutrients combined had a positive effect. In order to promote the micronutrient selenium, further details about selenium deficiencies and its health benefits need to be provided with the biofortified apples. Preferences for special product types (color print) should be considered.

\subsection{Influence of Health-Related Slogans}

The health-related slogans encompassed four different levels including two authorized health claims. The latter explained the benefits of selenium and iodine. The other two levels addressed, in addition to health aspects, the taste of the new biofortified apples and the natural content of micronutrients. Previous research has shown that physiological health claims would have a higher value if they were combined with a healthy carrier [52]. Similarly, the present results confirm a positive effect of health-related slogans on the willingness to purchase new biofortified apples. The results were thus also in line with previous studies that examined the importance of health claims [25,40,53,54]. In the case of selenium and iodine apples, consumers had a positive attitude toward the health claim regarding the normal functioning of the immune system. In contrast, the second health claim regarding normal thyroid function did not have a positive effect on the willingness to purchase. Furthermore, the slogans addressing the taste and the natural content of micronutrients of the apples had positive effects. Consequently, with regard to Q2, the health claim concerning the normal functioning of the immune system had the strongest effect on the willingness to purchase the new biofortifed apples. This provided sufficient background information about the innovative aspects of the new biofortified apples and stressed the additional benefits for the consumers.

\subsection{Influence of Variety and Brand Name}

In previous apple choice experiments conducted by Yue and Tong, varieties were associated with specific product characteristics such as taste or texture and were recognized by the consumers [35]. Since apple tastings could not be provided in our online approach, two varieties and two brand names for apples were included. Elstar and Braeburn were among the most often purchased apple varieties in Germany (Table 3). Pink Lady ${ }^{\circledR}$ was the most often purchased variety by $23.8 \%$ of the respondents. Since there had not been a comparable selenium- or iodine-rich apple in German retail previously, a brand name for a biofortified selenium apple was also included. It was called Selstar ${ }^{\circledR}$ and was shown to the consumers in the DCE for the first time [48]. The results showed that the two most common varieties Pink Lady ${ }^{\circledR}$ and Elstar had positive effects on the willingness to purchase the new biofortified apples. This was in line with previous research findings where variety had a positive effect and price a negative effect on the willingness to purchase apples [35,55]. This means that concerning Q3 and the variety, the German consumers acted as expected. Looking at the brand name Selstar ${ }^{\circledR}$, which represented a new name for selenium-rich apples, no effects on the willingness to purchase were found. Keeping in mind that the respondents had only just learned about this new brand name, the finding was not surprising. Since none of the consumers had ever heard of the name Selstar ${ }^{\circledR}$ nor seen it in German retail, none of the respondents could refer to a reference of this product. Among the three well established apple varieties and brands in the German market, the new name was not recognized. To sum up, the most common variety Pink Lady ${ }^{\circledR}$ had the strongest effect among the varieties or brand names. 


\subsection{Influence of Additional Purchase Motives}

The analysis of additional purchase motives in the DCE has shown that a positive effect on the willingness to purchase was found if the factor sustainability interacted with cardboard material and both jointly displayed micronutrients $\left(0.64^{* * *}\right)$ were considered and a negative effect if interacted with plastic packaging $\left(-0.38^{* *}\right)$. These findings were in line with current research findings regarding a negative attitude of German consumers toward plastic packaging. Recently, even a trend toward zero-packaging material could be observed. The prohibition of plastic bags in German retail was one example of the recent political decisions [56]. Consequently, the traditional plastic packaging B did not have positive effects on the willingness to purchase the new biofortified apples.

Apart from that, positive effects of the interaction of both micronutrients, the factor information requirement, and the cardboard packaging also reflected a recent trend in consumer behavior in Germany. With regard to production and processing methods and origin of food, consumers have become increasingly concerned [57]. For this reason, producers have increased their attempts to provide more detailed information regarding the supply and production chains of their products. In this manner, they have tried to overcome mistrust on the consumer side. Additionally, consumers tended to decide in favor of locally produced food products as they assumed a higher food safety [58].

The factor practicability, in contrast, did not have a significant effect on the willingness to purchase the new biofortified apples, regardless of the packaging material. It seemed that the benefits of easy handling and little efforts did not matter to a larger extent. However, the two factors, sustainability and information requirements, showed positive effects. In this DCE, a tendency toward more critical reflection of product information and environmentally friendly packaging material could be observed. With regard to Q5, plastic-free packaging material was found to be the preferred packaging in this DCE.

\subsection{Influence of Consumption of Food Supplements}

Previous research has demonstrated that the consumption of food supplements had increased in recent years [32]. For a lot of people, food supplements settled in the regular nutrition, and from the perspective of elderly people, they were considered as important as prescribed medicine for health [58]. In this research, $19.3 \%$ of the respondents mentioned that they had consumed iodine as a food supplement and $12.5 \%$ selenium. However, the idea that these consumers would be more attracted to the biofortified apples could not be verified. The interactions of both micronutrients, consumption of food supplements, and the packaging did not have significant effects. One possible explanation could be that the consumers of food supplements were already provided with sufficient micronutrients. Therefore, they did not need to consume the micronutrients in the form of apples anymore. However, it did not seem that they considered the biofortified selenium and iodine apples as equivalent to food supplements either. Another explanation could be that the apples were still unknown and consumers were not adequately convinced by the information provided in the questionnaire.

\subsection{Influence of Price}

The product price was included in the experiment to give consumers an indication of the costs they would have to spend for the new biofortified apples. The price steps were chosen based on market observations in German retail for similar apple products. Price had a negative impact on the willingness to purchase apples in previous research projects [29]. This was confirmed by the results of this DCE as well as the negative influence of price on the willingness to purchase apples.

\subsection{Limitations of the Present Study and Implications for Further Research}

Overall, the research approach implied the following limitations. The brand name Selstar ${ }^{\circledR}$ was included in the choice sets, but the consumer had never heard of it. No explanation was given beforehand. The pictures of the packaging were supposed to support 
the visual imagination of the product. However, they contained different colored apples, which could have influenced the respondents. The health-related slogan "Contributes to a normal functioning of the immune system" is not authorized for iodine. However, in the experiment, it was combined with iodine in the choice sets. If the results of this study are transferred to real products in the supermarkets, this constraint of research will have to be taken into consideration by the producers.

Furthermore, the choice experiment aimed at creating a decision situation, which was close to the shopping reality in German supermarkets. Nevertheless, the respondents were not aware of reference products from real supermarkets because the new biofortified apples were still at the developing stage. Given the challenge to combine specific micronutrient information and usual apple buying behavior knowledge, our approach was limited. It can be considered as a first approach in the field of consumer acceptance analysis with respect to biofortified apples. We could not refer to sophisticated previous research in this field and therefore had to reduce the discrete choice design as well as the statistical model to a manageable extent. Future research could build upon our results and identify more significant interactions between micronutrient information and further drivers of apple preferences, buying behavior, and socio-demographics.

In addition to this research, in a recently performed test launch in more than 300 outlets in Germany, around 50,000 units of selenium-biofortifed apples from the 2020 harvest were sold under the brand name "Selstar ${ }^{\circledR}$ ". In an accompanying customer survey $(\mathrm{n}=336)$, almost every second participant (49\%) stated that they particularly liked the Selstar's contribution to healthy nutrition. The majority of buyers $(87 \%)$ said that they would purchase this apple again, $12 \%$ were still undecided in this respect, and only less than $1 \%$ were no longer interested in the apple. The results indicate a very high acceptance level of selenium-rich apples among German consumers, which should also be further explored in future studies.

\section{Conclusions}

The DCE was conducted in a German online consumer survey to examine the impact of individual product attributes on the willingness to purchase biofortified apples prior to market launch. Considering the isolated effect of the micronutrient selenium, it was assumed that the benefits derived from the supply of selenium were not sufficiently communicated yet. In the case of iodine, a positive effect was found. If selenium and iodine biofortified apples shall serve as regular, natural selenium, and iodine source for vast parts of the German population in the future, the benefits of the consumption need to become more obvious to all consumers. The intensification of marketing at the point-of-sale could be one solution for that. More information about the consequences of insufficient supply with selenium on human health could be provided in order to increase the awareness for health problems that result from constant deficiencies. Generally, it should become more visible to the German population, where health damage could occur if the insufficient supply of these two essential micronutrients continued. Apart from that, the results of the DCE indicated that consumer purchase decisions were influenced by a set of product attributes. Common varieties and appropriate prices were crucial for the purchase decision of biofortified apples. However, given sufficient background information, the results suggest that micronutrients can also positively influence purchase decisions on apples. Micronutrients, especially those with limited awareness like selenium, should be combined with more well-known examples like iodine, health-related slogans, and relevant marketing attributes in order to make the products more preferable to consumers.

Author Contributions: R.K.-K. conceptualized the first draft of the manuscript and contributed significantly to the collection, preparation, and analysis of the data. A.P. contributed substantially to the data collection and analysis. All authors were involved in the interpretation of the data, and reviewed and revised the article. D.D. contributed substantially to the design of the study, has been continuously involved in drafting the manuscript, and initiated and headed the research project "BiofortiSe". U.E. contributed substantially to the design of the study, the preparation, and analysis 
of the data and has been continuously involved in drafting the manuscript. All authors have read and agreed to the published version of the manuscript.

Funding: This research was funded by the German Federal Ministry of Education and Research (BMBF) in the project "BiofortiSe" in the framework of the funding "Neue Produkte für die Bioökonomie" (Grant No. 031B0299A).

Institutional Review Board Statement: Not applicable.

Informed Consent Statement: Informed consent was obtained from all subjects involved in the study.

Data Availability Statement: The data presented in this study are available on request from the corresponding author. The data will be made publicly to a later stage.

Conflicts of Interest: The authors declare no conflict of interest.

\section{Appendix A}

Questionnaire A1.

Questionnaire regarding the purchase of apples Length of interview: approx. 10-15 $\mathrm{min}$

[Welcome text].

Hello!

The Osnabrueck University of Applied Sciences is conducting a consumer survey regarding the consumption of apples. It is part of a research project in cooperation with fruit growing farms. Please support us by contributing your personal experiences and ideas. The length of the interview is approximately 10-15 min. We invite you to take part in the survey!

In the following, we would like to ask you questions about your purchase habits of fresh apples.

1. How often do you consume fresh apples?

[IT: Single answer, mandatory field, screenout if Q1 <= 0]

2. When were you born?

$\begin{array}{ll}6 \square & \text { Usually daily } \\ 5 \square & \text { Several times per week } \\ 4 \square & \text { Weekly } \\ 3 \square & \text { Several times per month } \\ 2 \square & \text { Monthly } \\ 1 \square & \text { Rarely } \\ 0 \square & \text { Never } \rightarrow \text { Thank you and end of interview }\end{array}$

[IT: Mandatory field, show years as drop-down menu, quota]

\begin{tabular}{ccc}
\hline Years & Age Groups & $\%$ \\
\hline $2001-1995$ & $18-24$ & 10 \\
$1994-1985$ & $25-34$ & 18 \\
$1984-1975$ & $35-44$ & 17 \\
$1974-1965$ & $45-54$ & 23 \\
$1964-1949$ & $>54$ & 32 \\
\hline
\end{tabular}

1

3. Are you at least 18 years old or older?

[IT: Screenout if Q2.2 = 0, minimum age 18 years, mandatory field]

4. I am ...?

$1 \square \quad$ Yes

$0 \square \quad$ No $\rightarrow$ Thank you and end of interview

[IT: Mandatory field, quota]

\begin{tabular}{cl}
\hline Gender & $\%$ \\
Male & 50 \\
Female & 50 \\
\hline $1 \square$ & Male \\
$2 \square$ & Female
\end{tabular}

5. In which federal state do you live?

[IT: Single answer, drop-down menu, mandatory field, quota] 


Region
North
West
South
East

Federal states

Bremen, Hamburg, Mecklenburg-Vorpommern,

Niedersachsen oder Schleswig-Holstein

Nordrhein-Westfalen, Hessen, Rheinland-Pfalz oder Saarland

Bayern oder Baden-Württemberg Berlin, Brandenburg, Sachsen, Sachsen-Anhalt oder Thüringen
Quota

$18 \%$

$36 \%$

$28 \%$

$18 \%$

$\begin{array}{ll}1 \square & \text { Baden-Württemberg } \\ 2 \square & \text { Bayern } \\ 3 \square & \text { Berlin } \\ 4 & \text { Brandenburg } \\ 5 & \text { Bremen } \\ 6 & \text { Hamburg } \\ 7 & \text { Hessen } \\ 8 & \text { Mecklenburg-Vorpommern } \\ 9 & \text { Niedersachsen } \\ 10 & \text { Nordrhein-Westfalen } \\ 11 & \text { Rheinland-Pfalz } \\ 12 & \text { Saarland } \\ 13 & \text { Sachsen } \\ 14 & \text { Sachsen-Anhalt } \\ 15 & \text { Schleswig-Holstein } \\ 16 & \text { Thüringen }\end{array}$

Main questionnaire: IT: Filter all of the following questions via the last screening criterion.

6. Who is the main responsible for the grocery shopping in your household? [IT: Single answer, drop-down menu]

Mainly myself

Myself and another person

$1 \square$
$0 \square$

Usually someone else

7. Where do you purchase fresh apples most often?

[IT: Single answer]

$\begin{array}{ll}1 \square & \text { Discounter (e.g., Aldi) } \\ 2 \square & \text { Supermarket (e.g., Edeka, Marktkauf) } \\ 3 \square & \text { Shopping Centre (e.g., Galeria Kaufhof) } \\ 4 \square & \text { Weekly market } \\ 5 \square & \text { Organic grocery store } \\ 6 \square & \text { Farm store } \\ 7 \square & \text { I produce them myself (e.g., my own garden) } \\ \square & \text { Others }\end{array}$

8. In which packaging units did you purchase fresh apples at least once in the last year?

[IT: Multiple answers]

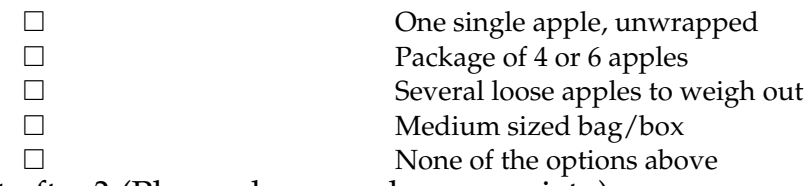

9. Which apple variety do you purchase most often? (Please choose only one variety)

[IT: randomize, single answer]

$\begin{array}{ll}1 \square & \text { Elstar } \\ 2 \square & \text { Boskoop } \\ 3 \square & \text { Jonagold } \\ 4 \square & \text { Gala } \\ 5 \square & \text { Golden Delicious } \\ 6 \square & \text { Braeburn } \\ 7 \square & \text { Granny Smith } \\ 8 \square & \text { Pink Lady } \\ 9 \square & \text { Kanzi } \\ 10 \square & \text { Cox Orange } \\ 11 \square & \text { Wellant } \\ 12 \square & \text { Holsteiner Cox } \\ 13 \square & \text { Fuji } \\ 14 & \text { Pinova } \\ 15 \square & \text { Topaz } \\ 16 \square & \text { Berlepsch } \\ 17 & \text { Cripps Pink }\end{array}$



$18 \square$
$19 \square$
Red Delicious
Red Prince
I prefer another variety which is:

10. In the following question we would like to show you a few statements regarding the purchase of locally produced apples. Please evaluate the statements considering your own experiences on the below scale from "always" to "never".

[IT: randomize]

$\begin{array}{ccccc}\text { I pay minor price premiums for apples that } & \text { Always } & \text { Often } & \text { Occasionally } & \text { Never } \\ \quad \text { are produced locally. } & 4 \square & 3 \square & 2 \square & 1 \square \\ \begin{array}{c}\text { I purchase locally produced apples to } \\ \text { support the local producers and farmers. }\end{array} & 4 \square & 3 \square & 2 \square & 1 \square \\ \begin{array}{c}\text { Buying locally produced apples is a } \\ \text { pleasant experience. }\end{array} & 4 \square & 3 \square & 2 \square & 1 \square \\ \text { I feel safer if I know where the products I } & 4 \square & 3 \square & 2 \square & 1 \square\end{array}$

11. Please choose three properties from the list below that describe natural food best in your opinion:

[IT: Multiple answers, randomize, maximum 3 answers]

"In my opinion natural food is ..."

... produced without the application of pesticides.

... free from food additives.

... raw or uncooked.

... a fresh product.

... produced without genetically modification.

... unaltered in taste.

... produced without the application of fertilizers. Other:

12. Please evaluate the statements below regarding fruits and vegetables. Please use a scale from "I totally agree" to "I totally disagree" to specify your opinion.

[IT: randomize]

\begin{tabular}{|c|c|c|c|c|c|}
\hline & agree & agree & & disagree agree & disagree \\
\hline $\begin{array}{l}\text { I like buying lose fruits in } \\
\text { order to choose the best } \\
\text { fruits myself. }\end{array}$ & $+2 \square$ & $+1 \square$ & $0 \square$ & $-1 \square$ & $-2 \square$ \\
\hline $\begin{array}{l}\text { I don't trust it if fruits and } \\
\text { vegetables look flawless. }\end{array}$ & $+2 \square$ & $+1 \square$ & $0 \square$ & $-1 \square$ & $-2 \square$ \\
\hline $\begin{array}{l}\text { If I buy apples, I prefer } \\
\text { commercial category } 1 .\end{array}$ & $+2 \square$ & $+1 \square$ & $0 \square$ & $-1 \square$ & $-2 \square$ \\
\hline I think original vegetables & & & & & \\
\hline $\begin{array}{l}\text { like e.g., curvy cucumbers } \\
\text { are appealing. }\end{array}$ & $+2 \square$ & $+1 \square$ & $0 \square$ & $-1 \square$ & $-2 \square$ \\
\hline $\begin{array}{l}\text { I buy strawberries and } \\
\text { asparagus only in the } \\
\text { respective harvesting } \\
\text { season. }\end{array}$ & $+2 \square$ & $+1 \square$ & $0 \square$ & $-1 \square$ & $-2 \square$ \\
\hline $\begin{array}{l}\text { High-quality fruits and } \\
\text { vegetables cannot be } \\
\text { produced without chemical } \\
\text { plant protection. }\end{array}$ & $+2 \square$ & $+1 \square$ & $0 \square$ & $-1 \square$ & $-2 \square$ \\
\hline
\end{tabular}

Information regarding trace elements in food

13. In the next part we would like to talk to you about trace elements. Which of the following trace elements have you ever heard of in the context of food?

[IT: Randomize, multiple answers, please fix the "none of the above" option below]

Fluorine
Cobalt
Molybdenum
Manganese
Copper
Zinc
Iron
Iodine
Selenium
None of the above


14. What is the first thing that comes to mind spontaneously if you hear the term selenium? [Processing instruction: You may answer in note form.]

15. What is the first thing that comes to mind spontaneously if you hear the term iodine? [Processing instruction: You may answer in note form.]

16. When you think about the effect of selenium and iodine on your body, how do you evaluate the effect?

$\begin{array}{ccccc}\begin{array}{c}\text { Definitely positive } \\ \text { effect }\end{array} & \begin{array}{c}\text { Rather positive } \\ \text { effect }\end{array} & \begin{array}{c}\text { Undecided } \\ \text { Selenium }\end{array} & \begin{array}{c}\text { Rather negative } \\ \text { effect }\end{array} & \begin{array}{c}\text { Definitely negative } \\ \text { effect }\end{array} \\ +2 \square & +1 \square & 0 \square & -1 \square & -2 \square \\ +2 \square & +1 \square & \begin{array}{c}\text { Iodine } \\ 0 \square\end{array} & -1 \square & -2 \square\end{array}$

(Number: 16_0) Qualityfail: Interrogation to measure the attention of the respondents: Continue with the questionnaire. Please choose number 5 on the scale below to continue with the questionnaire.

[IT: Screenout if choice $\neq 5$ ]

$\begin{array}{ccccc}1 & 2 & 3 & 4 & 5\end{array}$

17. Which of the following nutrients have you ever consumed in the form of food supplements?

[IT: Randomize, multiple answers, please fix "I do not consume any food supplements" and "Other" option below]

$\begin{array}{ll}\square & \text { Magnesium } \\ \square & \text { Vitamin C } \\ \square & \text { Zinc } \\ \square & \text { Vitamin D } \\ \square & \text { Iron } \\ \square & \text { Calcium } \\ \square & \text { B vitamins } \\ \square & \text { Folic acid } \\ \square & \text { Vitamin A } \\ \square & \text { Selenium } \\ \square & \text { Vitamin E } \\ \square & \text { Iodine } \\ \square & \text { I do not consume any food supplements } \\ \square & \text { Others }\end{array}$

18. How often do you consume these nutrients in the form of food supplements?

[IT: Please show all nutrients that were chosen in Q16 in order of Q16.]

\begin{tabular}{|c|c|c|c|c|c|c|}
\hline Rarely & $\begin{array}{c}\text { Once in } 3 \\
\text { Months }\end{array}$ & Monthly & $\begin{array}{l}\text { Several } \\
\text { Times per } \\
\text { Month }\end{array}$ & $\begin{array}{c}\text { Once per } \\
\text { Week }\end{array}$ & $\begin{array}{c}\text { Several } \\
\text { Times per } \\
\text { Week }\end{array}$ & Daily \\
\hline $1 \square$ & $2 \square$ & $3 \square$ & $4 \square$ & $5 \square$ & $6 \square$ & $7 \square$ \\
\hline $1 \square$ & $2 \square$ & $3 \square$ & $4 \square$ & $5 \square$ & $6 \square$ & $7 \square$ \\
\hline $1 \square$ & $2 \square$ & $3 \square$ & $4 \square$ & $5 \square$ & $6 \square$ & $7 \square$ \\
\hline $1 \square$ & $2 \square$ & $3 \square$ & $4 \square$ & $5 \square$ & $6 \square$ & $7 \square$ \\
\hline $1 \square$ & $2 \square$ & $3 \square$ & $4 \square$ & $5 \square$ & $6 \square$ & $7 \square$ \\
\hline & $2 \square$ & $3 \square$ & $4 \square$ & $5 \square$ & $6 \square$ & $7 \square$ \\
\hline \multicolumn{7}{|c|}{ ysfunction? } \\
\hline & & & $\begin{array}{l}1 \square \text { Yes } \\
0 \square \text { No }\end{array}$ & & & \\
\hline
\end{tabular}

21. Which allergies do you have? Please answer in note form.

19. Do you have a thyroid dysfunction?

$0 \square \mathrm{No}$

[IT: Filter: only if Q19 = 1]

Concept test: Introduction of a new apple variety

In the next section, we would like to introduce to you a new kind of apple which is especially rich in selenium and iodine. Selenium and iodine are essential micronutrients which contribute significantly to the improvement of human health. 


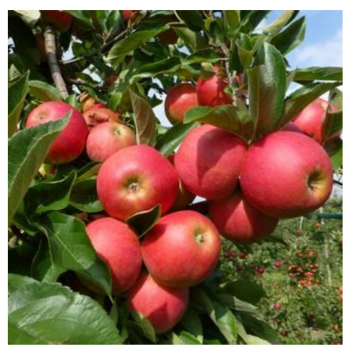

22. The first companies are currently launching the new biofortified apples in retail. Please imagine you are in a supermarket and would like to purchase a package of 6 apples. Which of the following apples would you choose? [IT: Conjoint question, question has to include the set variable, each question needs three answer options: A, B, C, forced choice-no "none of these" option, each set is a separate group]

\begin{tabular}{|c|c|c|c|}
\hline Version & $\begin{array}{l}\text { Picture of a partly } \\
\text { covered plain } \\
\text { cardboard } \\
\text { packaging }\end{array}$ & $\begin{array}{c}\text { B } \\
\begin{array}{c}\text { Picture of a plastic } \\
\text { bowl covered with } \\
\text { plastic foil }\end{array}\end{array}$ & $\begin{array}{c}\text { C } \\
\text { Picture of a fully } \\
\text { covered color } \\
\text { printed cardboard }\end{array}$ \\
\hline & $\begin{array}{l}\text { Contributes to a normal } \\
\text { thyroid functioning }\end{array}$ & $\begin{array}{l}\text { Naturally with } \\
\text { micronutrients }\end{array}$ & $\begin{array}{l}\text { Contributes to a normal } \\
\text { functioning of the } \\
\text { immune system }\end{array}$ \\
\hline Variety/brand & Elstar & Selstar & Braeburn \\
\hline Rich in & Selenium \& lodine & Selenium & / \\
\hline Price & $2.29 €$ & $2.29 €$ & $3.49 €$ \\
\hline
\end{tabular}

The new apples are not just rich in selenium and iodine; they can also have additional benefits.

23. How appealing are the following purchase reasons to you? Please use a scale from "Very appealing" to "Not appealing at all" to specify your opinion.

[IT: randomize items]

$\begin{array}{cccccc} & \begin{array}{c}\text { Very } \\ \text { appealing } \\ \text { to me }\end{array} & \begin{array}{c}\text { Rather } \\ \text { appealing } \\ \text { to me }\end{array} & \begin{array}{c}\text { Partly } \\ \text { Possible purchase reasons for new apples }\end{array} & \begin{array}{c}\text { Rather not } \\ \text { appealing } \\ \text { to me }\end{array} & \begin{array}{c}\text { Not } \\ \text { appealing } \\ \text { to me at all }\end{array} \\ \begin{array}{cccc}\text { Intense fruity taste } \\ +2 \square\end{array} & +1 \square & 0 \square & -1 \square & -2 \square \\ \text { Preferred apple variety: Elstar } & +2 \square & +1 \square & 0 \square & -1 \square & -2 \square \\ \text { Medium, handy fruit size } & +2 \square & +1 \square & 0 \square & -1 \square & -2 \square \\ \quad \text { Bright red fruit peel } & +2 \square & +1 \square & 0 \square & -1 \square & -2 \square \\ \text { Integrated production } & +2 \square & +1 \square & 0 \square & -1 \square & -2 \square \\ \quad \text { Locally produced } & +2 \square & +1 \square & 0 \square & -1 \square & -2 \square \\ \text { Freshly picked and crispy } & +2 \square & +1 \square & 0 \square & -1 \square & -2 \square \\ \quad \text { Produced in Germany } & +2 \square & +1 \square & 0 \square & -1 \square & -2 \square \\ \text { Especially suitable for vegetarian } & +2 \square & +1 \square & 0 \square & -1 \square & -2 \square \\ \quad \text { and vegan nutrition } & +2 \square & & & -1 \square \\ \text { Especially suitable for low allergy } & +2 \square & +1 \square & 0 \square & -1 \square & -2 \square \\ \quad \text { nutrition } & +2 \square & +1 \square & 0 \square & -1 \square & -2 \square\end{array}$




\begin{tabular}{cccccc}
\multicolumn{5}{c}{ Possible purchase reasons for packaging } \\
Aesthetic appealing packaging & $+2 \square$ & $+1 \square$ & $0 \square$ & $-1 \square$ & $-2 \square$ \\
Easy to open & $+2 \square$ & $+1 \square$ & $0 \square$ & $-1 \square$ & $-2 \square$ \\
$\quad$ No plastic in the packaging & $+2 \square$ & $+1 \square$ & $0 \square$ & $-1 \square$ & $-2 \square$ \\
$\begin{array}{c}\text { Further information available on } \\
\text { the Internet (e.g., via QR code) }\end{array}$ & $+2 \square$ & $+1 \square$ & $0 \square$ & $-1 \square$ & $-2 \square$ \\
$\begin{array}{c}\text { Imprint: “Certified by University } \\
\text { Medical Center Charité Berlin” }\end{array}$ & $+2 \square$ & $+1 \square$ & $0 \square$ & $-1 \square$ & $-2 \square$ \\
$\begin{array}{c}\text { Warranty of a long shelf life of the } \\
\text { fruits }\end{array}$ & $+2 \square$ & $+1 \square$ & $0 \square$ & $-1 \square$ & $-2 \square$
\end{tabular}

24. After hearing about the new apples, we would finally like to ask you how likely it is that you will buy the new apple products? Please use a scale from "Purchase is very likely" to "Purchase is very unlikely" to specify your intentions.

[IT: randomize]

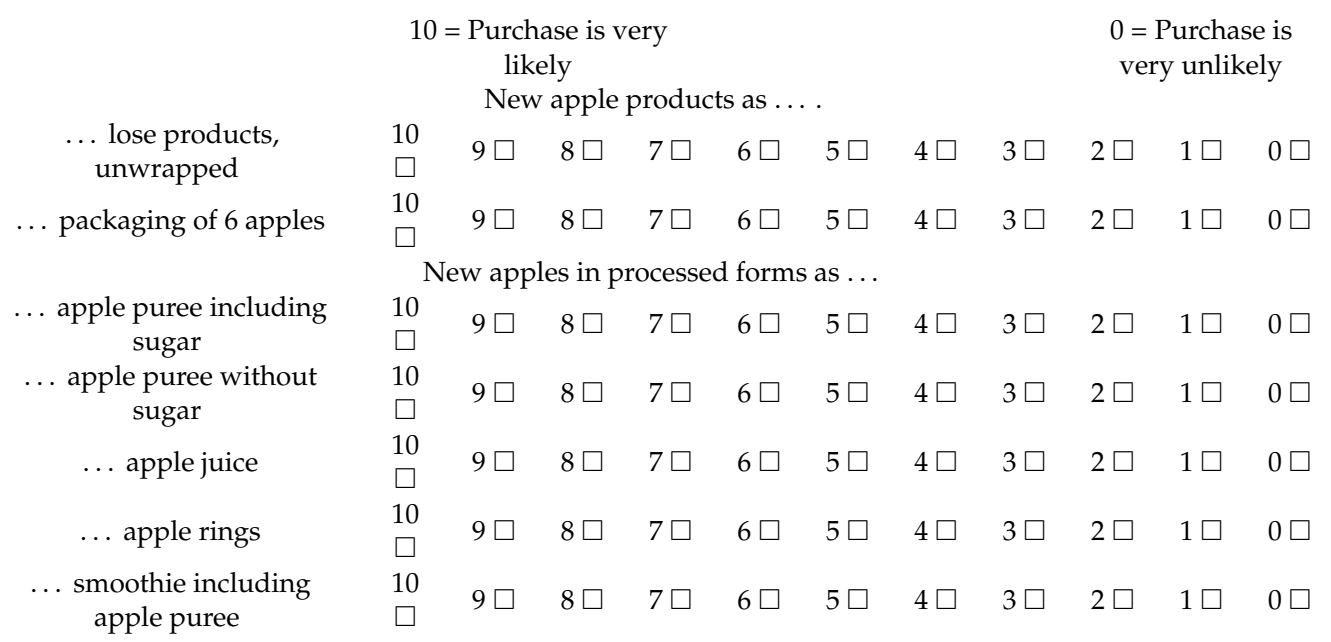

25. In the following, we would like to show you a few statements regarding general health aspects. Please use a scale from "I totally agree" to "I do not agree at all" to specify your opinion.

[IT: Randomize]

$$
\begin{aligned}
& \text { I am worried about chemicals in my } \\
& \text { food that are health endangerments. } \\
& \text { I am worried about the quality of } \\
& \text { my drinking water. } \\
& \text { I pay attention to the ingredients on } \\
& \text { the labels at the grocery shopping. } \\
& \text { The influence of nutrition on health } \\
& \text { is often overestimated. } \\
& \text { I never purchase products with } \\
& \text { health promoting effects. } \\
& \text { I never purchase ready-made } \\
& \text { dishes. }
\end{aligned}
$$

26. Do you pursue a particular nutrition?

$\begin{array}{ccccc}\begin{array}{c}\text { I totally } \\ \text { agree }\end{array} & \begin{array}{c}\text { I rather } \\ \text { agree }\end{array} & \text { Partly } & \begin{array}{c}\text { I rather do } \\ \text { not agree }\end{array} & \begin{array}{c}\text { I do not } \\ \text { agree at all }\end{array} \\ +2 \square & +1 \square & 0 \square & -1 \square & -2 \square \\ +2 \square & +1 \square & 0 \square & -1 \square & -2 \square \\ +2 \square & +1 \square & 0 \square & -1 \square & -2 \square \\ +2 \square & +1 \square & 0 \square & -1 \square & -2 \square \\ +2 \square & +1 \square & 0 \square & -1 \square & -2 \square \\ +2 \square & +1 \square & 0 \square & -1 \square & -2 \square\end{array}$

\section{[IT: Single answer, randomize]}


27. What is your highest educational level?

[IT: Mandatory question, single answer]

$$
\begin{aligned}
& 1 \square \text { Still in school } \\
& 2 \square \text { Primary school certificate } \\
& 3 \square \text { Secondary school certificate } \\
& 4 \square \text { A-Level (Abitur) } \\
& 5 \square \text { Technician/Master } \\
& 6 \square \text { University degree } \\
& 0 \square \text { No education } \\
& \square \text { Other }
\end{aligned}
$$

28. Which of the following professions best describe your current level of employment?

[IT: Single answer]

$$
\begin{aligned}
& 1 \square \text { Still in school } \\
& 2 \square \text { Professional training } \\
& 3 \square \text { Enrolled in university } \\
& 4 \square \text { Full-time worker } \\
& 5 \square \text { Part-time worker } \\
& 6 \square \text { Pension/retirements } \\
& 7 \square \text { Housewife/househusband } \\
& 8 \square \text { Unemployed } \\
& 0 \square \text { No answer }
\end{aligned}
$$

\begin{tabular}{|c|c|c|c|c|c|}
\hline Choice Set & Packaging & Health-Related Slogan & Variety/Brand & Micronutrients/Rich-In & Price \\
\hline \multirow{3}{*}{1} & A & Contributes to a normal thyroid functioning & Pink Lady ${ }^{\circledR}$ & Iodine & $2.29 €$ \\
\hline & $\mathrm{B}$ & Contributes to a normal thyroid functioning & Selstar $^{\circledR}$ & Iodine & $2.99 €$ \\
\hline & $\mathrm{C}$ & Contributes to a normal thyroid functioning & Pink Lady ${ }^{\circledR}$ & Iodine & $2.99 €$ \\
\hline \multirow{3}{*}{2} & A & Contributes to a normal thyroid functioning & Selstar ${ }^{\circledR}$ & Iodine & $2.29 €$ \\
\hline & $\mathrm{B}$ & Naturally with micronutrients & Elstar & / & $2.49 €$ \\
\hline & $\mathrm{C}$ & Contributes to a normal thyroid functioning & Pink Lady ${ }^{\circledR}$ & Iodine & $2.99 €$ \\
\hline \multirow{3}{*}{3} & A & Contributes to a normal thyroid functioning & Selstar ${ }^{\circledR}$ & Iodine & $2.29 €$ \\
\hline & $\mathrm{B}$ & Contributes to a normal thyroid functioning & Pink Lady ${ }^{\circledR}$ & Iodine & $2.99 €$ \\
\hline & $\mathrm{C}$ & Contributes to a normal thyroid functioning & Braeburn & Iodine & $2.49 €$ \\
\hline \multirow{3}{*}{4} & A & Contributes to a normal functioning of the immune system & Selstar ${ }^{\circledR}$ & / & $2.49 €$ \\
\hline & $\mathrm{B}$ & Contributes to a normal thyroid functioning & Pink Lady ${ }^{\circledR}$ & Iodine & $2.49 €$ \\
\hline & $\mathrm{C}$ & Contributes to a normal thyroid functioning & Selstar ${ }^{\circledR}$ & Iodine & $2.99 €$ \\
\hline \multirow{3}{*}{5} & A & Contributes to a normal thyroid functioning & Selstar ${ }^{\circledR}$ & Iodine & $2.99 €$ \\
\hline & $\mathrm{B}$ & Contributes to a normal thyroid functioning & Pink Lady ${ }^{\circledR}$ & Iodine & $2.29 €$ \\
\hline & $\mathrm{C}$ & Naturally with micronutrients & Elstar & Selenium & $3.49 €$ \\
\hline \multirow{3}{*}{6} & A & Naturally with micronutrients & Elstar & Selenium \& Iodine & $3.49 €$ \\
\hline & $\mathrm{B}$ & Contributes to a normal thyroid functioning & Selstar ${ }^{\circledR}$ & Iodine & $2.29 €$ \\
\hline & $\mathrm{C}$ & Contributes to a normal thyroid functioning & Pink Lady ${ }^{\circledR}$ & / & $2.49 €$ \\
\hline \multirow{3}{*}{7} & A & Contributes to a normal thyroid functioning & Elstar & Selenium \& Iodine & $2.29 €$ \\
\hline & $\mathrm{B}$ & Naturally with micronutrients & Selstar ${ }^{\circledR}$ & Selenium & $2.29 €$ \\
\hline & $\mathrm{C}$ & Contributes to a normal functioning of the immune system & Braeburn & / & $3.49 €$ \\
\hline \multirow{3}{*}{8} & A & Naturally with micronutrients & Braeburn & / & $2.49 €$ \\
\hline & $\mathrm{B}$ & Contributes to a normal functioning of the immune system & Pink Lady ${ }^{\circledR}$ & Selenium \& Iodine & $3.49 €$ \\
\hline & $\mathrm{C}$ & Contributes to a normal thyroid functioning & Selstar ${ }^{\circledR}$ & Selenium & $2.29 €$ \\
\hline \multirow{3}{*}{9} & A & Naturally with micronutrients & Selstar ${ }^{\circledR}$ & / & $2.99 €$ \\
\hline & $\mathrm{B}$ & Contributes to a normal functioning of the immune system & Elstar & / & $2.49 €$ \\
\hline & $\mathrm{C}$ & Contributes to a normal thyroid functioning & Braeburn & Selenium & $3.49 €$ \\
\hline \multirow{3}{*}{10} & A & Tasty \& healthy enjoyment & Elstar & Selenium \& Iodine & $3.49 €$ \\
\hline & $\mathrm{B}$ & Contributes to a normal thyroid functioning & Braeburn & Selenium & $2.29 €$ \\
\hline & $\mathrm{C}$ & Contributes to a normal thyroid functioning & Selstar ${ }^{\circledR}$ & Iodine & $2.49 €$ \\
\hline \multirow{3}{*}{11} & A & Contributes to a normal functioning of the immune system & Selstar ${ }^{\circledR}$ & Selenium & $3.49 €$ \\
\hline & $\mathrm{B}$ & Contributes to a normal thyroid functioning & Pink Lady ${ }^{\circledR}$ & Selenium \& Iodine & $2.29 €$ \\
\hline & $\mathrm{C}$ & Tasty \& healthy enjoyment & Elstar & / & $2.49 €$ \\
\hline
\end{tabular}

29. How many people belong to your household in total?

[IT: Single answer, show drop-down menu with number of persons]

$$
\begin{aligned}
& 1 \square 1 \text { person } \\
& 2 \square 2 \text { persons } \\
& 3 \square 3 \text { persons } \\
& 4 \square 4 \text { persons } \\
& 5 \square 5 \text { persons } \\
& 6 \square \text { More than } 5 \text { people } \\
& 0 \square \text { No answer }
\end{aligned}
$$

30. Thereof _ children younger than 12 years

[IT: filter: only if Q29 > 1]

\section{I___ I children}

Table A1. 20 choice sets. 
Table A1. Cont.

\begin{tabular}{|c|c|c|c|c|c|}
\hline Choice Set & Packaging & Health-Related Slogan & Variety/Brand & Micronutrients/Rich-In & Price \\
\hline \multirow{4}{*}{12} & A & Tasty \& healthy enjoyment & Elstar & Selenium & $3.49 €$ \\
\hline & $\mathrm{B}$ & Naturally with micronutrients & Braeburn & Selenium & $3.49 €$ \\
\hline & $\mathrm{C}$ & Contributes to a normal thyroid functioning & Selstar ${ }^{\circledR}$ & Selenium \& Iodine & $2.29 €$ \\
\hline & A & Contributes to a normal thyroid functioning & Braeburn & Iodine & $2.29 €$ \\
\hline \multirow[t]{2}{*}{13} & $\mathrm{~B}$ & Contributes to a normal functioning of the immune system & Selstar ${ }^{\circledR}$ & Selenium & $2.29 €$ \\
\hline & $\mathrm{C}$ & Tasty \& healthy enjoyment & Pink Lady ${ }^{\circledR}$ & Selenium \& Iodine & $3.49 €$ \\
\hline \multirow{4}{*}{14} & A & Tasty \& healthy enjoyment & Braeburn & Selenium \& Iodine & $3.49 €$ \\
\hline & $\mathrm{B}$ & Naturally with micronutrients & Pink Lady ${ }^{\circledR}$ & / & $3.49 €$ \\
\hline & $\mathrm{C}$ & Contributes to a normal thyroid functioning & Elstar & Selenium & $2.29 €$ \\
\hline & A & Naturally with micronutrients & Pink Lady ${ }^{\circledR}$ & Selenium & $3.49 €$ \\
\hline \multirow[t]{3}{*}{15} & $\mathrm{~B}$ & Tasty \& healthy enjoyment & Braeburn & Selenium \& Iodine & $2.29 €$ \\
\hline & $\mathrm{C}$ & Contributes to a normal thyroid functioning & Elstar & Selenium \& Iodine & $3.49 €$ \\
\hline & A & Contributes to a normal functioning of the immune system & Braeburn & / & $3.49 €$ \\
\hline \multirow[t]{3}{*}{16} & B & Naturally with micronutrients & Elstar & Selenium \& Iodine & $2.29 €$ \\
\hline & $\mathrm{C}$ & Tasty \& healthy enjoyment & Selstar ${ }^{\circledR}$ & Selenium & $2.49 €$ \\
\hline & A & Tasty \& healthy enjoyment & Braeburn & / & $2.49 €$ \\
\hline \multirow{3}{*}{17} & $\mathrm{~B}$ & Contributes to a normal functioning of the immune system & Elstar & Selenium & $2.49 €$ \\
\hline & $\mathrm{C}$ & Contributes to a normal thyroid functioning & Elstar & / & $2.99 €$ \\
\hline & A & Contributes to a normal functioning of the immune system & Elstar & Selenium \& Iodine & $2.99 €$ \\
\hline \multirow[t]{3}{*}{18} & $\mathrm{~B}$ & Contributes to a normal thyroid functioning & Braeburn & / & $3.49 €$ \\
\hline & $\mathrm{C}$ & Tasty \& healthy enjoyment & Elstar & / & $2.49 €$ \\
\hline & A & Contributes to a normal functioning of the immune system & Braeburn & / & $2.99 €$ \\
\hline \multirow[t]{3}{*}{19} & $\mathrm{~B}$ & Contributes to a normal thyroid functioning & Selstar ${ }^{\circledR}$ & Selenium \& Iodine & $2.99 €$ \\
\hline & $\mathrm{C}$ & Tasty \& healthy enjoyment & Braeburn & Selenium & $2.29 €$ \\
\hline & A & Tasty \& healthy enjoyment & Pink Lady ${ }^{\circledR}$ & Selenium & $2.99 €$ \\
\hline \multirow{2}{*}{20} & $\mathrm{~B}$ & Contributes to a normal thyroid functioning & Braeburn & Selenium & $2.99 €$ \\
\hline & $\mathrm{C}$ & Tasty \& healthy enjoyment & Braeburn & Selenium \& Iodine & $2.99 €$ \\
\hline
\end{tabular}

\section{References}

1. Thomson, C.D.; McLachlan, S.K.; Grant, A.M.; Paterson, E.; Lillico, A.J. The effect of selenium on thyroid status in a population with marginal selenium and iodine status. Br. J. Nutr. 2005, 94, 962-968. [CrossRef] [PubMed]

2. Stoffaneller, R.; Morse, N.L. A review of dietary selenium intake and selenium status in Europe and the Middle East. Nutrients 2015, 7, 1494-1537. [CrossRef]

3. Combs, G.F. Selenium in global food systems. Br. J. Nutr. 2001, 85, 517-547. [CrossRef]

4. Poňavič, M.; Scheib, A. Distribution of Selenium in European Agricultural and Grazing Land Soil. In Chemistry of Europe's Agricultural Soils_Part B: General Background Information and Further Analysis of the GEMAS Data Set-Geologisches Jahrbuch (Reihe B103); Reimann, C., Birke, M., Demetriades, A., Filzmoser, P., O'Connor, P., Eds.; Schweizerbart: Stuttgart, Germany, 2014; pp. 131-144. ISBN 978-3-510-96847-3.

5. Jones, G.D.; Droz, B.; Greve, P.; Gottschalk, P.; Poffet, D.; McGrath, S.P.; Seneviratne, S.I.; Smith, P.; Winkel, L.H.E. Selenium deficiency risk predicted to increase under future climate change. Proc. Natl. Acad. Sci. USA 2017, 114, 2848-2853. [CrossRef]

6. Salminen, R.; Batista, M.J.; Bidovec, M.; Demetriades, A.; de Vivo, B.; de Vos, W.; Duris, M.; Gilucis, A.; Gregorauskiene, V.; Halamic, J.; et al. Geochemical Atlas of Europe, Part 1, Background Information, Methodology and Maps. Geological Survey of Finland. 2005. Available online: http:/ / weppi.gtk.fi/publ/foregsatlas/part2.php (accessed on 11 May 2021).

7. Fuge, R.; Johnson, C.C. Iodine and human health, the role of environmental geochemistry and diet, a review. Appl. Geochem. 2015, 63, 282-302. [CrossRef]

8. Gärtner, R. Recent data on iodine intake in Germany and Europe. J. Trace Elem. Med. Biol. 2016, 37, 85-89. [CrossRef] [PubMed]

9. Fessler, B. Deutschland-Ein Jodmangelland. Pädiatrie 2019, 31, 62.

10. Aburto, N.J.; Abudou, M.; Candeias, V.; Wu, T. Effect and Safety of Salt Iodization to Prevent Iodine Deficiency Disorders: A Systematic Review with Meta-Analyses; WHO eLibrary of Evidence for Nutrition Actions (eLENA): Geneva, Switzerland, 2014.

11. Kipp, A.P.; Strohm, D.; Brigelius-Flohé, R.; Schomburg, L.; Bechthold, A.; Leschik-Bonnet, E.; Heseker, H.; German Nutrition Society (DGE). Revised reference values for selenium intake. J. Trace Elem. Med. Biol. 2015 32, 195-199. [CrossRef]

12. Schöne, F.; Spörl, K.; Leiterer, M. Iodine in the feed of cows and in the milk with a view to the consumer's iodine supply. J. Trace Elem. Med. Biol. 2017, 39, 202-209. [CrossRef]

13. Dávila-Rangel, I.E.; Leija-Martínez, P.; Medrano-Macías, J.; Fuentes-Lara, L.O.; González-Morales, S.; Juárez-Maldonado, A.; Benavides-Mendoza, A. Iodine Biofortification of Crops. In Nutritional Quality Improvement in Plants; Jaiwal, P., Chhillar, A., Chaudhary, D., Jaiwal, R., Eds.; Springer: Cham, Switzerland, 2019; pp. 79-113.

14. Eurola, M.; Ekholm, P.; Ylinen, M.; Koivistoinen, P.; Varo, P. Effects of Selenium Fertilization on the Selenium Content of Cereal Grains, Flour, and Bread Produced in Finland. Cereal Chem. 1990, 67, 334-337.

15. Budke, C.; Mühling, K.H.; Daum, D. Iodine uptake and translocation in apple trees grown under protected cultivation. J. Plant Nutr. Soil Sci. 2020, 183, 468-481. [CrossRef]

16. Budke, C.; thor Straten, S.; Mühling, K.H.; Broll, G.; Daum, D. Iodine biofortification of field-grown strawberries-Approaches and their limitations. Sci. Hortic. 2020, 269, 109317. [CrossRef] 
17. Groth, S.; Budke, C.; Neugart, S.; Ackermann, S.; Kappenstein, F.S.; Daum, D.; Rohn, S. Influence of a Selenium Biofortification on Antioxidant Properties and Phenolic Compounds of Apples (Malus domestica). Antioxidants 2020, 9, 187. [CrossRef] [PubMed]

18. Budke, C.; Dierend, W.; Schön, H.-G.; Hora, K.; Mühling, K.H.; Daum, D. Iodine Biofortification of Apples and Pears in an Orchard Using Foliar Sprays of Different Composition. Front. Plant Sci. 2021, 12. [CrossRef] [PubMed]

19. D'Amato, R.; Regni, L.; Falcinelli, B.; Mattioli, S.; Benincasa, P.; Dal Bosco, A.; Pacheco, P.; Proietti, P.; Troni, E.; Santi, C.; et al. Current Knowledge on Selenium Biofortification to Improve the Nutraceutical Profile of Food: A Comprehensive Review. J. Agric. Food Chem. 2020, 68, 4075-4097. [CrossRef] [PubMed]

20. Pezzarossa, B.; Remorini, D.; Gentile, M.L.; Massai, R. Effects of foliar and fruit addition of sodium selenate on selenium accumulation and fruit quality. J. Sci. Food Agric. 2012, 92, 781-786. [CrossRef]

21. Newman, R.; Waterland, N.; Moon, Y.; Tou, J.C. Selenium Biofortification of Agricultural Crops and Effects on Plant Nutrients and Bioactive Compounds Important for Human Health and Disease Prevention-A Review. Plant Foods Hum. Nutr. 2019, 74, 449-460. [CrossRef]

22. Medrano-Macías, J.; Leija-Martínez, P.; González-Morales, S.; Juárez-Maldonado, A.; Benavides-Mendoza, A. Use of Iodine to Biofortify and Promote Growth and Stress Tolerance in Crops. Front. Plant Sci. 2016, 7, 1146. [CrossRef]

23. Roberfroid, M.B. Global view on functional foods: European perspectives. Br. J. Nutr. 2002, 88, 133-138. [CrossRef] [PubMed]

24. Kunz, C.; Schulz, S. Funktionelle Lebensmittel: Mehr als ein Trend? Chemie Unserer Zeit 2004, 38, 120-127. [CrossRef]

25. Annunziata, A.; Vecchio, R. Consumer perception of functional foods: A conjoint analysis with probiotics. Food Qual. Prefer. 2013, 28, 348-355. [CrossRef]

26. Wortmann, L.; Enneking, U.; Daum, D. German Consumers' Attitude towards Selenium-Biofortified Apples and Acceptance of Related Nutrition and Health Claims. Nutrients 2018, 10, 190. [CrossRef] [PubMed]

27. Garming, H.; Dirksmeyer, W.; Bork, L. Entwicklungen des Obstbaus in Deutschland von 2005 bis 2017: Obstarten, Anbauregionen, Betriebsstrukturen und Handel. Thünen Work. Pap. 2018. [CrossRef]

28. Hanke, M.-V.; Flachowsky, H. Obstzüchtung und Wissenschaftliche Grundlagen; Springer: Berlin, Germany, 2017; ISBN 978-3-662-54084-8.

29. Denver, S.; Jensen, J.D. Consumer preferences for organically and locally produced apples. Food Qual. Prefer. 2014, 31, 129-134. [CrossRef]

30. Mogendi, J.B.; de Steur, H.; Gellynck, X.; Makokha, A. A novel framework for analysing stakeholder interest in healthy foods: A case study on iodine biofortification. Ecol. Food Nutr. 2016. [CrossRef] [PubMed]

31. Cox, D.N.; Bastiaans, K. Understanding Australian consumers' perceptions of selenium and motivations to consume selenium enriched foods. Food Qual. Prefer. 2007, 18, 66-76. [CrossRef]

32. Willers, J.; Heinemann, M.; Bitterlich, N.; Hahn, A. Intake of Minerals from Food Supplements in a German Population-A Nationwide Survey. Food Nutr. Sci. 2015, 6, 205-215. [CrossRef]

33. Bonany, J.; Buehler, A.; Carbó, J.; Codarin, S.; Donati, F.; Echeverria, G.; Egger, S.; Guerra, W.; Hilaire, C.; Höller, I.; et al. Consumer eating quality acceptance of new apple varieties in different European countries. Food Qual. Prefer. 2013, 30, 250-259. [CrossRef]

34. Villatoro, C.; López, M.L.; Echeverria, G.; Graell, J. Effect of controlled atmospheres and shelf life period on concentrations of volatile substances released by 'Pink Lady' apples and on consumer acceptance. J. Sci. Food Agric. 2009, 89, 1023-1034. [CrossRef]

35. Yue, C.; Tong, C. Consumer Preferences and Willingness to Pay for Existing and New Apple Varieties: Evidence from Apple Tasting Choice Experiments. HortTechnology 2011, 21, 376-383. [CrossRef]

36. Harker, F.R.; Gunson, F.A.; Jaeger, S.R. The case for fruit quality: An interpretive review of consumer attitudes, and preferences for apples. Postharvest Biol. Technol. 2003, 28, 333-347. [CrossRef]

37. Wurm, F.R.; Spierling, S.; Endres, H.-J.; Barner, L. Plastics and the Environment-Current Status and Challenges in Germany and Australia. Macromol. Rapid Commun. 2020, 41. [CrossRef]

38. White, A.; Lockyer, S. Removing plastic packaging from fresh produce-What's the impact? Nutr. Bull. 2020, 45, 35-50. [CrossRef]

39. Profeta, A. The Impact of Health Claims in Different Product Categories. J. Int. Food Agribus. Mark. 2020, 32, 123-140. [CrossRef]

40. Hung, Y.; Verbeke, W. Consumer evaluation, use and health relevance of health claims in the European Union. Food Qual. Prefer. 2019, 74, 88-99. [CrossRef]

41. Asioli, D.; Næs, T.; Øvrum, A.; Almli, V.L. Comparison of rating-based and choice-based conjoint analysis models. A case study based on preferences for iced coffee in Norway. Food Qual. Prefer. 2016, 48, 174-184. [CrossRef]

42. Naes, T.; Lengard, V.; Bolling Johansen, S.; Hersleth, M. Alternative methods for combining design variables and consumer preference with information about attitudes and demographics in conjoint analysis. Food Qual. Prefer. 2010, 21, 368-378. [CrossRef]

43. Louviere, J.J.; Flynn, T.N.; Carson, R.T. Discrete Choice Experiments Are Not Conjoint Analysis. J. Choice Model. 2010, 3, 57-72. [CrossRef]

44. McFadden, D. Conditional Logit Analysis of Qualitative Choice. In Frontiers in Econometrics; Zarembka, P., Ed.; Academic Press: New York, NY, USA, 1973; pp. 105-142.

45. Enneking, U.; Neumann, C.; Henneberg, S. How important intrinsic and extrinsic product attributes affect purchase decision. Food Qual. Prefer. 2007, 18, 133-138. [CrossRef]

46. European Commission. EU Register on Nutrition and Health Claims. Available online: https://ec.europa.eu/food/safety/ labelling_nutrition/claims/register/public/? event=search (accessed on 3 December 2020).

47. Bonany, J.; Brugger, C.; Buehler, A.; Carbó, J.; Codarin, S.; Donati, F.; Echeverria, G.; Egger, S.; Guerra, W.; Hilaire, C.; et al. Preference mapping of apple varieties in Europe. Food Qual. Prefer. 2014, 32, 317-329. [CrossRef] 
48. Kleine-Kalmer, R.; Daum, D.; Enneking, U. Consumer behavior analysis for biofortified selenium apples and implications for conducting a market test in German food retailing. Acta Hortic. 2021. accepted.

49. Choicemetrics. Ngene 1.2 User Manual E Reference Guide; Technical Report; Choicemetrics, Sydney. 2018. Available online: http: / / www.choice-metrics.com/NgeneManual120.pdf (accessed on 12 March 2021).

50. Steptoe, A.; Pollard, T.M.; Wardle, J. Development of a Measure of the Motives Underlying the Selection of Food: The Food Choice Questionnaire. Appetite 1995, 25, 267-284. [CrossRef] [PubMed]

51. Kirchhoff, V.K.; Herrmann, R. Verbrauchereinstellungen zum Salz- und Jodsalzkonsum in Lebensmitteln: Eine Befragungsstudie. Ber. Landwirtsch. Z. Agrarpolit. Landwirtsch. 2020, 98. [CrossRef]

52. Siegrist, M.; Stampfli, N.; Kastenholz, H. Consumers' willingness to buy functional foods. The influence of carrier, benefit and trust. Appetite 2008, 51, 526-529. [CrossRef]

53. Ballco, P.; de Magistris, T. Spanish Consumer Purchase Behaviour and Stated Preferences for Yoghurts with Nutritional and Health Claims. Nutrients 2019, 11, 2742. [CrossRef]

54. Benson, T.; Lavelle, F.; Bucher, T.; McCloat, A.; Mooney, E.; Egan, B.; Collins, C.E.; Dean, M. The Impact of Nutrition and Health Claims on Consumer Perceptions and Portion Size Selection: Results from a Nationally Representative Survey. Nutrients 2018, 10, 656. [CrossRef] [PubMed]

55. Harker, F.R.; Kupferman, E.M.; Marin, A.B.; Gunson, F.A.; Triggs, C.M. Eating quality standards for apples based on consumer preferences. Postharvest Biol. Technol. 2008, 50,70-78. [CrossRef]

56. Mederake, L.; Hinzmann, M.; Langsdorf, S. Hintergrundpapier: Plastikpolitik in Deutschland und der EU: Aktuelle Gesetze und Initiativen. 2020. Available online: https://bmbf-plastik.de/sites/default/files/2020-08/20-08-04_Hintergrundpapier_ Plastikpolitik-final.pdf (accessed on 29 January 2021).

57. Hempel, C.; Hamm, U. Local and/or organic: A study on consumer preferences for organic food and food from different origins. Int. J. Consum. Stud. 2016, 40, 732-741. [CrossRef]

58. Plasek, B.; Lakner, Z.; Kasza, G.; Temesi, Á. Consumer Evaluation of the Role of Functional Food Products in Disease Prevention and the Characteristics of Target Groups. Nutrients 2019, 12, 69. [CrossRef] 